\title{
Mouse models for radiation-induced cancers
}

\section{Leena Rivina ${ }^{1, \dagger}$, Michael J. Davoren $^{1, *, \dagger}$ and Robert H. Schiest| ${ }^{1-4}$}

\begin{abstract}
'Department of Environmental Health Sciences, ${ }^{2}$ Department of Pathology and Laboratory Medicine and ${ }^{3}$ Department of Radiation Oncology, University of California, Los Angeles, 650 Charles E. Young Dr. South, CHS 71-295, Los Angeles, CA 90095, USA and 4JCCC Healthy and At-Risk Populations Program Area, 650 Charles E. Young Dr. South, CHS 71-295, Los Angeles, CA 90095, USA
\end{abstract}

\begin{abstract}
*To whom correspondence should be addressed. Tel: +1 310267 2593; Fax: +1 310267 2578; Email: mdavoren@g.ucla.edu †These authors contributed equally to this work.
\end{abstract}

Received 23 May 2014; Revised 31 March 2016; Accepted 4 April 2016.

\begin{abstract}
Potential ionising radiation exposure scenarios are varied, but all bring risks beyond the simple issues of short-term survival. Whether accidentally exposed to a single, whole-body dose in an act of terrorism or purposefully exposed to fractionated doses as part of a therapeutic regimen, radiation exposure carries the consequence of elevated cancer risk. The long-term impact of both intentional and unintentional exposure could potentially be mitigated by treatments specifically developed to limit the mutations and precancerous replication that ensue in the wake of irradiation The development of such agents would undoubtedly require a substantial degree of in vitro testing, but in order to accurately recapitulate the complex process of radiation-induced carcinogenesis, well-understood animal models are necessary. Inbred strains of the laboratory mouse, Mus musculus, present the most logical choice due to the high number of molecular and physiological similarities they share with humans. Their small size, high rate of breeding and fully sequenced genome further increase its value for use in cancer research. This chapter will review relevant $m$. musculus inbred and $F_{1}$ hybrid animals of radiation-induced myeloid leukemia, thymic lymphoma, breast and lung cancers. Method of cancer induction and associated molecular pathologies will also be described for each model.
\end{abstract}

\section{Introduction}

Cancer is, at its core, a disease of time-the accumulation of the specific cocktail of mutations necessary to yield a population of cancerous cells usually takes many years. As the United States population ages, cancer rates increase and will only continue to increase for the forseeable future. The medical technology, drug regimens and techniques we use to treat cancer cases also continue to improve, leading to long-term survival of cancer patients at unprecedented rates. According to present models, $50 \%$ of US citizens will receive a cancer diagnosis in their lifetimes, and half of these will receive radiation therapy as a part of their course of treatment-a rate hardly unique among developed nations $(1,2)$. Radiotherapy is sometimes used as the sole avenue of cancer therapy, but it is more commonly received in combination with as chemotherapeutic drugs, molecular targeted therapy or immunotherapy. The use of radiation therapy is not confined to the treatment of cancers, either: it is also routinely used for immunosuppression in the cases of bone marrow, stem cell and organ transplantation (3). The unparalleled ability of radiation to kill cancer cells, however, does not come without cost. It is impossible to completely prevent collateral damage to healthy tissues when irradiating a tumor site. This damage can result in acute radiation toxicity, but more insidiously can increase the risk of chronic secondary malignancies down the line, specifically radiation-induced cancer $(4,5)$. Even the diagnostic use of radiation in medicine comes with a collateral cost. Indeed, epidemiology from fluoroscope-induced breast cancer rates contributed much to our knowledge of radiation-induced breast cancers (6). Despite much lower exposure times and dose-rates when compared with treatment-seeking radiation therapy, the use of diagnostic techniques such as CT scans and PET tracers also take their toll in terms of DNA damage $(7,8)$.

Unnecessary exposure of healthy surrounding tissues continues to be reduced by advances in radiation delivery technology. This more targeted delivery leads to more effective tumor killing as well, 
increasing the therapeutic ratio (9-12). Even so, the complexities of tumor growth and interactions between cancer and the body within the tumor microenvironment will always lead to some collateral exposure. The development of alternate cotherapies is therefore an imperative to reduce the risk of both secondary tumors and acute toxicities resulting from radiation therapy.

Potential interventions against the side effects of purposeful radiation exposure would not have their value limited to that sole avenue of application, either; a treatment with demonstrated effects against both primary and secondary radiation-induced malignancies in the clinical setting would prove invaluable in far uglier, less intentional scenarios as well. The risk of a terrorist attack utilising the release of radiation or radioactive material is considered to be a very real threat by the United States government (13), and the meltdown of the Fukushima Daiichi reactor in 2011 radiation release incident demonstrates that unintentional, massive amounts of radiation exposure are possible as well. Organisations like the National Cancer Institute (NCI) have recognised the gap in our medical capability to respond to radiation emergencies, and identified research priorities (14). Obviously, interventions that prevent immediate death from acute radiation injury take precedence, but the need for treatment plans that lessen the risk of eventual complications in survivors, like cancer, has also been recognised (15).

When discussing the potential types of compounds that could be administered to reduce radiation damage, whether to prevent damage to the healthy tissue surrounding the tumor site, or to reduce sustained genotoxicity after accidental exposure to radiation, it is helpful to divide them into three classes. A first class of radiation protectors would consist of agents applied prior to radiation exposure. An ideal radioprotector would offer differential protection to healthy tissue over tumor, and allow for higher, more effective tumor-killing doses-perhaps by taking advantage in differences of DNA repair function (16) Radiation mitigators, a second class, would maintain efficacy when applied post-exposure (PE), but prior to the onset of symptoms. Agents such as these could focus on treating organ failure-level effects, such as radiation-induced neuropathy (17) or nephropathy (18), or might ideally prevent celllevel damage after the insult. The third class, therapies, would be administered after the onset of symptoms, and likely focus on treating these symptoms rather than their causes (19). Currently, only a single agent is approved by the Food and Drug Administration (FDA) for the purpose of reducing radiation damage to healthy tissue. This agent, amifostine (20), falls into the first category, as intravenous administration is given a few minutes prior to radiotherapy in clinical practice. The medical research community recognises that a single, limited treatment is not sufficient to meet the needs of future radiation oncology-and comes up dreadfully short in a disaster exposure scenario. The NCI, in collaboration with National Institute of Allergy and Infectious Diseases (NIAID) has developed an algorithm to appraise agents designed to reduce the detrimental effects of cancer therapies, and prepare them for clinical development (21). In order for a candidate agent to meet these stringent standards, success in animal model is a mandatory prerequisite. Another workshop reached similar conclusions with regards to accidental radiation exposure (14). This chapter seeks to supply researchers developing these types of interventions with a comprehensive description of animal models relevant to the adverse effects of radiation, specifically the increased risk of cancers. Models specialised for the investigation of the more acute toxicities resulting from exposure to radiation have been covered previously to great effect by Williams and Colleagues (22).

\section{Methods}

\section{Research strategy}

Over the course of the last century of biological research, the laboratory mouse Mus musculus has been our ever present companion, a cornerstone of in vivo research and the go-to model for any study requiring the complex environment of a living mammalian body. Thousands of strains are now available for research use, and ever more specialised mice are constantly under development. The field of cancer research is no exception. Modern mouse strains are often specialised in order to mimic exceptionally precise or specific aspects of carcinogenesis or a corresponding pathology. Xenograft models or humanised mice can be used directly with human neoplastic cells or to express aberrant human proteins. Other engineered strains exist which develop a certain type of cancer, developing along an exact, planned path, after exposure to a specific carcinogen. Genetically engineered mice, or GEM, represent the pinnacle of in vivo modeling of highly focused research into narrow portions of carcinogenetic processes. They are often the most accurate way of recapitulating the peculiarities or underlying molecular mechanisms of the human disease (23). For this reason, GEM are often used in lieu of more traditional inbred mouse strains. They often develop tumors more quickly and at more predictable intervals.

However, the very same precision that characterises GEM as superior tools for answering highly specific questions about a cancer acts as a potential drawback when investigating alternative mechanisms of cancer formation. GEM are usually developed to follow an exact carcinogenesis pathway. While this can be helpful to many research projects, one would not be able to draw many general conclusions when testing novel compounds or hypothetical alternative mechanisms. The purview of GEM rests strongly in their powerful ability to refine existing disease pathways or test highly targeted interventions. In this way, inbred strains remain the best choice for 'ground-level' investigations into the process of cancer development, as well as agents that affect that process. The use of inbred mice was indispensable for the initial discoveries of the oncogenes and tumor suppressors that were later manipulated to derive dedicated strains of GEM, as well as the toxic and therapeutic effects of countless agents (24). The value of inbred strains is still apparent, especially when it comes to investigating interventions that may act through less well understood mechanisms, such as those against radiationinduced cancer risk.

The same reasoning for why inbred mouse models remain superior to GEM for general cancer induction and progression studies might also beg the question as to why outbred strains are not preferred. After all, outbred strains should show greater genetic heterogeneity than inbred strains, serving as a more accurate model of the genetic diversity in a human population. This very heterogeneity, though, can become a liability when it comes to running a carcinogenesis experiment. When examining any process with both environmental and genetic components, such as cancer development in response to radiation, minimising the genetic variance between individuals is critical to the ability to determine experimental significance with sufficient power. Greater variance between individual outbred mice often means that significantly more mice are required (25). The level of genetic heterogeneity in a given outbred stock can vary greatly in terms of the number of polymorphic loci present (26). Population bottlenecks in outbred stock can lead to genetic drift, an issue made worse between varying levels of quality control between suppliers (27). Indeed, the change in allele frequency of any outbred population over time can make it very difficult to make use of 
previously published information regarding that strain, even if the mice are obtained from the same supplier. Each user must therefore recharacterise the strain of interest prior to beginning an experiment (25). Even if concerned about the potential for one strain's genetic resistance to a particular insult, it is generally more efficient to use multiple strains of inbred mice than a single outbred strain (28).

The purpose of this review is to identify and describe inbred mouse models of radiation-induced (RI) cancers, with a focus on using them to investigate interventions against their development. Central emphasis will be placed on myeloid leukemia, lung, and breast cancers as most common subtypes of cancer to arise after radiation therapy (5).

\section{Inclusion criteria}

Murine models discussed in this review are limited to those pertaining to radiation-induced carcinogenesis of lymphomas, leukemias, breast and lung cancers. In particular, focus will be placed on inbred models in which cancer is induced following exposures to 'Low LET' (linear energy transfer) gamma- and X-ray irradiations. These models are most relevant to the dose rates healthy tissue is exposed to during such radiotherapy procedures as the Gamma Knife (29). 'High-LET' radiation inductions, GEM and xenograft models are outside of the scope of this work. Most of the models described rely solely on radiation for tumor induction, with a few special exceptions (SJL/J mice). Models described include total body irradiation (TBI) and localised IR induction methods as well as fractionated and single dose schemes. When comparing mouse induction to human radiation treatment, mouse fractionation is often split to a far lesser degree, largely due to issues of practicality. Despite this difference, disease induction is often quite comparable in terms of relative latency and pathology. Although we hope to draw general conclusions that apply to both primary and secondary RI cancers, mouse exposure scenarios are limited to primary radiation induction of tumors due to experimental feasibility.

Another point should be clarified regarding the radiation induction of cancers. Cancer progression generally requires multiple successive mutations in order to be officially recognised. Oftentimes, 'initiating' mutations can lie dormant—on their own, they are insufficient to cause the cell to progress to metastatic disease. Only after a subsequent 'promoting' insult is sustained will a traditional progression model become applicable. While some mutagens characteristically act as one or the other, Ionising radiation is a 'complete carcinogen,' capable of both induction and promotion (30-32). In many of these models, the radiation induction we discuss actually functions as the inducer of a promoting mutation. In many cases, oncogenes may already be active in both experimental animals and humans from birth (33), and it is the factors that facilitate the expansion of these cells that can be said to induce carcinogenesis (34). Details on specific mechanisms of promotion can be found in the molecular pathology sections below.

The ultimate goal of research using these models will be to develop interventions for human disease. For this reason, the models chosen constitute those that most closely mimic the underlying molecular pathologies of each type of cancer as observed in humans, maximising clinical relevance.

\section{Results and discussion}

\section{Radiation-induced myeloid leukemia}

Leukemia was one of the first cancers to have its link with radiation well documented. In the infancy of radiation research, the long-term dangers posed by constant exposure were not well understood. Radiation safety standards were quite lax by today's standards, and many cases of leukemia likely arose in early scientists and radiologists working with unshielded sources of ionising radiation (35). This early link was, in fact, supported by experiments demonstrating that ionising radiation could lead to leukemia in laboratory mice as early as the 1930s (36). Unfortunately, it was decades before this correlation between radiation exposure and leukemia mortality was noted to be anything more than anecdotal. The first studies to truly lend significant epidemiological evidence to these risks were the Life Span Studies, following both Atomic Bomb survivors and therapeutic radiation patients, treated for such diseases as cervical cancer, tinea capitis and ankylosing spondylitis (37-42). A particularly incisive study by Boice and colleagues established a sharp increase in leukemia incidence following radiation treatment for the uterine cervix carcinoma (43). Additional data emerged in the wake of the Chernobyl disaster. Detailed records on the excess risk estimates for the development of leukemia in populations analyzed by such factors as age and estimated exposure level have come to light for analysis in the last few decades. For example, clear associations were drawn from people and cleanup workers exposed to higher doses of radiation (44), while the link is more tenuous for populations exposed to under $\sim 0.5 \mathrm{mSv}$ (45). Though the circumstances of the event were tragic, information garnered in its aftermath has provided a far more complete data set on age-dependence, doses and latencies (46-49).

These studies provide risk evidence from a wide range of exposure scenarios, irradiation rates, sources and doses. By comparing the data, scientists were able to identify salient features common to all irradiation induced leukemias. The two most commonly observed RI-induced cancers in an adult population are both myeloid leukemias, of the acute (AML) or chronic (CML) subtypes $(39,40,42,50$ 52). The subtype of leukemia most commonly seen in children varies by age of exposure. Younger children exposed around 5-9 years of age more generally develop acute lymphocytic leukemia (ALL), while children exposed after the age of 10 are more likely to develop AML. A fourth type of leukemia risk, that of chronic lymphocytic leukemia (CLL) does not seem to correlate with radiation exposure in the same manner as the others, exhibiting only a weak link if any $(53,54)$. Leukemia after radiation exposure can arise relatively rapidly, with the highest risk observed in the decade immediately following initial exposure. After this period, relative risk decreases, albeit never returning to the baseline level of an unirradiated individual $(39,40,46,51,55)$. Relative risk for developing different subtypes of leukemia has also been observed to vary by other factors, including the sex of the patient $(40,42,46,50)$. The relative risk of contracting leukemia roughly doubled in one study following women receiving radiation treatment for endometrial cancer, whether exposed to low, constant dose rates or high, fractionated ones. This study estimated about 14 excess cancers per 10000 IR-treated individuals (56).

Epidemiological data is a valuable starting point for any study of radiation-induced cancer, as it provides a background against which any experimental data from models can be checked for relevance. Interventions, however, demand the use of models for preliminary testing. Clinical trials in patients undergoing radiation therapy can provide primary human data, but only after extensive vetting as part of FDA approval. Similarly, an experimental intervention in humans could potentially be justified in the aftermath of a radiation catastrophe, but even in such a case an intervention must at least be partially understood before use. Murine models, therefore, are absolutely essentially for the process of understanding the mechanisms of induction of RI-induced carcinogenesis, improving risk diagnostics and especially furthering the development of radiation protection 
and mitigation efforts. Several well-characterised mouse models of leukemia are available, including RF $(57,58), \mathrm{SJL} / \mathrm{J}$ (59), CBA $(60,61)$ and $\mathrm{C} 3 \mathrm{H} / \mathrm{He}(62)$. The following table, adapted from our previous review, summarises the optimal induction method, associated ML frequencies and other relevant features of each model (63) (Table 1).

\section{RF mouse}

The RF mouse was developed at the Rockefeller Institute for use as a general-purpose stock from the A, R and S strains $(25,58)$. The strain has a relatively high proclivity for IR-induced leukemogenesis, as studied by Upton and colleagues (64). Some of the earliest accounts of radiation-induced leukemia took place using this strain, from observations in mice exposed to nuclear detonations in experiments conducted by Furth and colleagues $(65,66)$. Myelogenous leukemia (ML) is induced in this strain with a single unfractionated dose of ionising radiation. This method of induction is generally considered to closely mimic human disease progression, exhibiting diagnosable tissue lesions during a prolonged preclinical period (58).

A low background rate of leukemic development is present in this strain. Between 18-24 months of age, roughly $2-4 \%$ of even unirradiated RF mice develop myeloid leukemia (68). This lifetime incidence rate is boosted up to $40 \%$ upon exposure of 8 -week-old RF males to 1.5 Gy of ionising radiation. Paradoxically, in utero and neonatal irradiations actually decrease ML induction $(57,64)$. Higher doses of IR (4.25 Gy) increases disease penetrance further to between 50 and $90 \%$ of animals, with a latency period of 4-6 months $(58,68,69)$. Useful elements of disease progression can be observed in this model as well. The accumulation of immature myeloid cells in the spleen and liver of progressing animals can be measured as early as 12 weeks post exposure. The infiltration of leukemic cells can be observed in peribronchial areas, lymph nodes and gastrointestinal lymphoid organs. One potential confounding drawback of this model is that thymic lymphoma is also induced in $25 \%$ of mice irradiated at the dose necessary to induce myeloid leukemia, which could interfere with accurate ML diagnosis and disease modelling (58). Sex differences in susceptibility were also demonstrated by Upton and colleagues. Thymic lymphoma is more common in female mice, while males are more likely to develop ML. This gives the possibility of mixed hematopoietic tumors of both myeloid leukemic and thymic lymphoma origin presenting in the model, limiting its utility (57).

Characteristic chromosomal rearrangements are visible in the karyotypes of cells undergoing leukemic progression in this strain. According to Hayata et al., ML in the RF model typically exhibits partial deletion of chromosome 2 and total loss of the Y-chromosome (although he regards this loss of $\mathrm{Y}$ as a mere artifact of cell proliferation rather than involved in leukemogenesis) (70), similarly to the $\mathrm{SJL} / \mathrm{J}$ mouse discussed next (71). One of the strengths of this model is that the several month latency of ML in RF mice correlates well with human data. As stated previously, the peak incidence of leukemia diagnoses occurred 5-10 years post exposure in both Japanese atomic bomb survivors and children exposed to the Chernobyl disaster $(40,46,50,72)$. Radiotherapy induced leukemia occurs on a slightly shorter, but still similar, latency period of 2.5-7 years (73).

\section{SJL/J mouse}

The SJL/J strain was developed in 1960 by Murphy and colleagues. It is known for the high spontaneous frequency of reticulum cell neoplasms (type B, RCN B) occurring in one third of mice roughly a year after birth in both sexes (74-76). This strain has also been proposed as a model for the study of Hodgkin's Lymphoma, as the histological pattern of these RCNs presents quite similarly to that of human Hodgkin's disease (77).

One whole body 3-3.5 Gy exposure in 8-10-week-old female $\mathrm{SJL} / \mathrm{J}$ mice induces myeloid leukemia in $10-30 \%$ of animals. Fractionated X-ray doses have been observes to induce lymphosarcomas as well (77). Leukemic infiltration can be observed in the bone marrow, lymph nodes, spleen and liver, consistent with observation of human AML (59). The percentage of animals that develop radiation-induced acute myeloid leukemia actually increases the later the age to exposure, up until 12 weeks. This increase in susceptibility is likely explained by the maturation of the mouse's mononuclear phagocytic system, which occurs at this time (76).

Radiation alone is sufficient to initiate RI-AML in this strain. In order to better recapitulate all aspects of this complex, multiphase malignancy, though, additional promoting factors are generally administered (78). In the overwhelming majority of irradiated mice, preleukemic cells exhibiting characteristic chromosome 2 deletions can be observed in the bone marrow early on. Clinical presentation of overt AML occurs at $90-120$ days $(79,80)$. As stated previously, however, this only occurs in $10-30 \%$ of IR-treated mice. A followup administration of corticosteroids increases RI-AML incidence to $50-70 \%(59)$. Further reduced latencies and increased frequencies of $\sim 75 \%$ can be reached by co-administration of growth factors such as colony stimulating factor-1 (CSF-1) $(78,81)$. The decision to investigate this particular factor was based on the observation that, 2-4 months prior to onset, mice that would go on to develop AML solely after radiation had significantly elevated CSF-1 levels as compared to those that developed RCN-B or no cancer at all. RI-AML cells in vitro can also be observed to synthesise significant amounts of CSF-1, further supporting the hypothesis that high CSF-1 is correlated with leukemia progression (76).

The presentation of RI-AML in the SJL/J mouse strongly resembles that observed in humans (59). AML is diagnosed at relatively high frequencies in patients with Hodgkin's Disease in remission after receiving radiotherapy and steroid regimens-mimicking the combination induction in the mouse quite closely $(82,83)$. This correlation between a Hodgkin's Disease/RCN B background state and the induction of RI-AML afterwards makes SJL/J an extremely valid RI-AML model for this particular set of circumstances. Both this strain of mice and Hodgkin's Disease patients tend to develop

Table 1. Induction of myeloid leukemia in mice with low-LET ionising radiation

\begin{tabular}{|c|c|c|c|c|c|c|c|c|}
\hline Mouse strain & Age & Sex & Dosage & Fractionation & Latency & $\begin{array}{l}\text { Spontaneous } \\
\text { frequency }\end{array}$ & $\begin{array}{l}\text { Induced } \\
\text { frequency }\end{array}$ & Ref. \\
\hline $\mathrm{RF}(\mathrm{RF} / \mathrm{J}, \mathrm{RFM})$ & 8 weeks & Male & 4.25 Gy & Single dose & 4-12 months & $2-4 \%$ & $50-90 \%$ & $(57,58)$ \\
\hline $\mathrm{SJL} / \mathrm{J}$ & $8-10$ weeks & Female & 3-3.5 Gy & Single dose & 12 months & $0 \%$ & $10-30 \%$ & (59) \\
\hline $\mathrm{C} 3 \mathrm{H} / \mathrm{He}$ & $8-10$ weeks & Male & 2.84 Gy & Single dose & $1.5-18$ months & $<1 \%$ & $25 \%$ & $(60,61)$ \\
\hline $\mathrm{CBA}(\mathrm{CBA} / \mathrm{Ca}, \mathrm{CBA} / \mathrm{Cne}, \mathrm{CBA} / \mathrm{H})$ & $12-15$ weeks & Male & 3 Gy & Single dose & $18-24$ months & $<1 \%$ & $25 \%$ & (62) \\
\hline
\end{tabular}


myeloid leukemias of the acute rather than the chronic type (84). Elevated serum CSF-1 has also been reported in some neoplastic malignancies, including AML and appears to be associated with poor prognosis (85-88).

\section{$\mathrm{C} 3 \mathrm{H}$ mouse}

The C3H strain is one of biology's oldest and most widely used, developed by Strong in 1920 from a cross of the Bragg Albino mouse and the DBA mouse. Dams in the strain were specifically selected for elevated incidence of mammary tumors (MT). Ninety percent of unfostered pups develop mammary tumors by 11 months of age. This peculiarity of cancer incidence is due to the transfer of mouse mammary tumor virus (MMTV) into the offspring via the mother's milk. Fostering newborn animals or transferring fertilised ova to a surrogate free of MTV significantly reduces the tumor development frequency (25). However, the fostered $\mathrm{C} 3 \mathrm{H} / \mathrm{He}$ substrain exhibits a high incidence of spontaneous hepatomas later in life $(62,89)$.

A total of $23.9 \%$ of $8-10$-week-old male $\mathrm{C} 3 \mathrm{H} / \mathrm{He}$ mice develop myeloid leukemia after a single whole body X-irradiation of 3 Gy. Myelomonocytic leukemia is by far the most prevalent subtype. Female mice are significantly less susceptible to induction (90). The dose-response curves of $\mathrm{C} 3 \mathrm{H}$ mice appear quite similar to those of RFM and the CBA strains. Leukemic induction frequency increases proportionally with level of radiation received until a critical dose at around $3 \mathrm{~Gy}$, after which the incidence of ML drops rapidly (60). The administration of the synthetic glucocorticoid prednisolone following irradiation increases the incidence of ML to $38.5 \%$, a scenario similar to promotion with corticosteroids in SJL/J mice (59). Unirradiated $\mathrm{C} 3 \mathrm{H}$ mice have a spontaneous leukemia incidence under $1 \%$, and that rate can be entirely eliminating with caloric restriction to $2 / 3$ of a normal diet (62). Caloric restriction is even effective at reducing the incidence of RI-ML down to $7.9 \%$ if restriction is started prior to 6 weeks of age, or as low as $10.7 \%$ if CR begins after irradiation, at 10 weeks of age (91). Caloric restriction's effectiveness likely involves the suppression of pro-growth signaling via insulin pathway modulation (92). Chronic inflammation is also implicated as an exacerbating factor in the promotion of leukemogenesis. They also demonstrated that chronic low-level inflammation, induced by insertion of a cellulose acetate membrane, increases RI-ML incidence to $35.9 \%$ (90).

In the $\mathrm{C} 3 \mathrm{H} / \mathrm{He}$ strain, just as in RFM and $\mathrm{SJL} / \mathrm{J}$ mice, the partial deletion of chromosome 2 is observed in RI-AML development $(70,93)$. Chromosome 2 deletions can be detected in the bone marrow as early as the first metaphase occurring post irradiation, suggesting a critical initiating role in the process of leukemogenesis (94). $\mathrm{The} \mathrm{Ph}^{1}$ chromosome transformation common to human chronic myeloid leukemia, can be compared to these murine chromosome 2 aberrations in terms of both incidence and disease specificity $(95,96)$.

\section{CBA mouse}

CBA mice, like C3H mice, were developed by Strong around 1920. They too are derived from crossing brag Albino and DBA mice, but in this case while specifically selecting for low background mammary tumor incidence. The two major substrains, CBA/Ca and $\mathrm{CBA} / \mathrm{H}$, encompass the majority of descendants of the original mice from the UK $(97,98)$. Male CBA/Ca mice have a shorter lifespan then females (25).

Irradiating 12-week-old male $\mathrm{CBA} / \mathrm{H}$ mice with $3 \mathrm{~Gy}$ of $\mathrm{X}$ or Gamma spectrum radiation induces myeloid leukemia in $25 \%$ of mice. As the disease progresses after a long latency period (generally over 1.5 years), metastases occur in sternal bone marrow, liver and splenic tissue, serving as a diagnostic endpoint $(60,61)$. As in the previously discussed models, the induction kinetics of RI-induced leukemia are curvilinear, implying a threshold dose is necessary to initiate. Furthermore, much higher doses do not induce leukemia at all. This fact correlates well with human epidemiology $(99,100)$.

Again, abnormalities in the structure of chromosome 2 can be observed in over $20 \%$ of the mice irradiated at this level $(98,101,102)$. Such abnormalities can be observed from as early as $20 \mathrm{~h}$ after IR, to as late as 24 months after (103). Although presentation of chromosome 2 defects would be consistent with leukemic progression in that clone of cells, Bouffler et al. were unable to prove that the presence of an aberrant chromosome 2 clone will conclusively predict eventual development of RI-AML in CBA mice (104). Abnormalities of chromosome 4 can also be observed in half of cases of AML in this strain. The loss of Lyr2/TLSR 5 via deletion or translocation was identified as a likely event in disease progression by Cleary et al. (105). Epigenetic changes can be observed as well. After irradiation in this model, an $8 \%$ decrease in in DNA-methylation is present. As this decrease is not observed in AML-resistant C57Bl/6, this change could be associated with the $\mathrm{CBA} / \mathrm{H}$ mouse's greater RI-AML susceptibility (106).

The CBA mouse is the preferred genetically unmodified mouse model for RI-AML. Advantages include a low spontaneous frequency of AML and a close resemblance to human RI-AML in disease morphology $(97,107)$. Based on extrapolation of induction kinetics by X-ray and neutron exposure, Dekkers et al have suggested that a "two-hit" model of RI-AML induction in CBA/H. This requirement of multiple mutations for progression makes for a more useful model of human RI-AML (108).

\section{ML-associated molecular pathologies}

As previously mentioned, the development of chromosome 2 anomalies are a common observation in multiple mouse models (RF, C3H/ $\mathrm{He}, \mathrm{CBA}$ and $\mathrm{SJL} / \mathrm{J}$ ) and tend to associate with their development of acute myelogenous leukemia $(70,71,93)$. Rodents have high rates of chromosomal recombination when compared with humans, so determining the directly corresponding piece human chromosome for a given mouse segment is often a daunting task (109). Amongst the genes present on mouse chromosome 2 is the Abl gene, famous for its fusion into the Bcr-Abl fusion protein in the Philadelphia chromosome. Although the Philadelphia chromosome is usually associated with CML, it can also be found in ALL and other leukemic lineages $(110,111)$. The involvement of this gene could be considered as a factor in these mice, but in mice, the lesion here generally takes the form of a deletion. Because of this, it was already assumed that the gene responsible for leukemia initiation was likely a tumor suppressor rather than a proto-oncogene, like Abl (112). The guilty party was identified by Cook and colleagues as the sfpil gene in 2004 after identifying the general location as a common region of loss of heterozygosity (LOH) $(112,113)$. This gene, found in the $2 \mathrm{Mbp}$ region commonly missing in AML mice, encodes the transcription factor PU.1 (114).

PU.1 is a key transcription factor in normal hematopoiesis, involved in promotion, differentiation and regulation of every hematopoietic lineage. It is essential for both proper stem cell maintenance and the terminal differentiation of macrophages and neutrophils (115-119). The PU.1 protein includes multiple domains including DNA binding, protein-protein interaction and regulatory phosphorylation domains imperative for controlled function (120). In developing hematopoietic cells, lower levels of PU.1 lead to lymphocyte fates, while higher levels lead to myeloid fates. 
Proper function is required for successful development in both cases $(121,122)$. However, its importance in equivalent human transformations is still a subject of active debate $(114,123,124)$.

Primary allelic loss is often caused by a deletion of the aforementioned $2 \mathrm{Mbp}$ region from chromosome 2; the second copy of sfpi1 is often inactivated via point mutations in its DNA binding region, yielding a nonfunctional protein $(114,123)$. Homozygous conditional knockdown of PU.1 in the bone marrow, reducing expression levels to only $20 \%$ of wild type, induces AML in mice inactivated from birth by 3-8 months of age (125). Induction can be achieved via inactivation in adult mice as well (126). Also not sufficient for leukemic transformation alone, the malfunction of this gene is commonly found paired with other mutations and gene losses in leukemia. The loss of PU.1 function via a chromosome 2 deletion is a common 'second hit' leukemogenesis event in transgenic mice already expressing the oncoprotein PML-PAR (127). Upregulation of $c-m y c$ has also been reported accompanying PU.1 deficiencies in AML cells (128). Interestingly, the forced expression of PU.1 at normal levels in promyelocitic leukemia cells inhibited clonogenic growth, forced monocytic differentiation and induced apoptosis, supporting the hypothesis that the suboptimal expression of PU.1 can promote leukemogenesis by blocking proper maturation of the cell $(114,119)$. Peng et al. (129) have suggested the quantification of PU.1-deleted bone marrow cells as a surrogate marker for RI-AML.

Given these data, it would be tempting to declare PU.1 a tumor suppressor. However, other studies have shown that overexpression of the very same transcription factor can lead to other cancers, in particular erythroleukemias (130). It would be more correct to argue that PU.1 is a critical transcription factor involved in the differentiation of multiple hematopoietic lineages, the dysregulation of which serves the development of many leukemic variants.

The human ortholog of PU.1, encoded by the SPI1 gene, is on chromosome 11 (119), and is expressed at low levels in most AML cases, as might be predicted from the mouse models (131). In contrast with mouse models, though, its inactivation by deletion is comparatively rare in humans $(123,124)$. Other mechanisms of PU.1 deactivation have been suggested to take precedence in human AML. The gene could be epigenetically silenced, or inactivated through interaction with a mutated receptor (i.e. the Flt3 cytokine receptor found in $25 \%$ of human AML) or another protein (114). The aberrant expression of certain miRNAs, specifically miR-155, has also been suggested as a cause of reduced PU.1 expression (132). Finnon et al. supported this possibility with the observation that Flt3-ITD and Sfpi1/PU.1 mutations are mutually exclusive in murine radiation-induced AML. Regardless of which gene is mutated, there is no overt phenotypic difference, suggesting that the two are capable of playing an equivalent role in the oncogenesis process (133).

As stated previously, the kinetics of IR-induction of myeloid leukemia in these models suggests that two hits are necessary. It remains to be proven, however, whether radiation is generally responsible for both of these events. Current understanding points strongly towards irradiation as the source of Spfi1 deletions $(80,93,129)$. The deletion could result from direct damage such as breaks in the DNA induced by ionising radiation itself, or secondary genomic instability such as that caused by IR-induced free radicals (135-137). For the loss of the second allele, however, radiation is not the most likely candidate, as IR does not induce the point mutations often observed in Spfi1 $(114,123,128)$. That type of mutation is more likely to be of spontaneous origin, and would generally be rectified via homologous repair mechanisms if not for its deleted counterpart $(137,139)$.
Ban and Kai demonstrated that hematopoietic stem cells (HCS) surviving $3 \mathrm{~Gy}$ of radiation are subjected to replicative stress, contributing to their accelerated senescence. This increased rate of replication decreases replicative fidelity and increases the rate of mutation accumulation, increasing the chance of a point mutation in the remaining copy of the Spfi1 gene. Mathematical models fitted to experimental data from cobblestone area forming cells (CAFC) and colony forming unit-granulocyte/macrophages (CFU-G/M) on ex vivo bone marrows revealed that irradiated HSCs cycle as much as 10 times more quickly than HSCs in unexposed animals (138).

Hirouchi et al. (107) challenged the commonly accepted paradigm that HSCs are the sole genitors of RI-AML, concluding that the cancer can arise from long-lived HSCs, short-lived multipotent progenitors (MPPs) and even common myeloid progenitors (CMPs) that have acquired self-renewal potential. They postulate that the inactivation of Dusp2 on chromosome 2 is another likely contributor. Cell surface phenotypes and gene expression profiles of the AML stem cells isolated in their study often resembled CMPs more closely than they did HSCs (139).

Even though mouse chromosomes do not directly correlate with human chromosomes, it is useful to identify commonly deleted or otherwise aberrant regions, as genes that are directly correlated with the human disease are often found in these 'trouble spots'. Chromosome 2 has been identified as a particular trouble spot in RI-AML, as stated several times before. Other loci on chromosomes 8,13 and 18 have also been identified as involved in leukemogenesis. RBBP8, a BRCA1 modulator present on chromosome 18, is upregulated in response to $\mathrm{X}$-ray exposure in RI-AML-sensitive CBA mice but not the RI-AML-resistant strain C57BL/6 (140).

\section{Radiation-induced lymphoma}

Although readily inducible in rodents, the link between lymphoma and exposure to ionising radiation in humans is not as strong as that between IR and leukemia. Evidence supports at least minor correlation between radiotherapy and certain types of lymphomas, according to Hartge and colleagues $(141,142)$. Other investigators have cautioned that found the link between non-Hodgkin's lymphoma (NHL) and radiation exposure is excessively weak, and that there may be no association at all between IR and Hodgkin's disease (40,143-145). Certain epidemiological studies, however, tip the scales of evidence in favor of an association. Richardson et al showed a strong link between ionising radiation and lymphoma mortality among men exposed to irradiation at the Savannah River Site in South Carolina. Skepticism over the strength of the IR-lymphoma link is probably due to the disease's protracted latency and obscure mechanism of induction, which make it more difficult to point to IR as the directly responsible agent (146).

In rodent pathological classification, no difference has been historically drawn between lymphomas and lymphocytic leukemias. Malignant lymphomas have traditionally been subdivided into six classifications, and described further based on the tumor site as thymic, mesenteric or leukemic (147). Prior to necropsy, researchers must often turn to indirect observations of animal symptoms to diagnose lymphoma. Generic moribund symptoms such as labored breathing and hunched posture, taken along with the specific lymphomic elements of spleen and lymph node enlargement, are indications of fulminant malignancy. When enlarged spleens or lymph nodes are not readily visible in moribund mice, animals are usually suspected to have a thymic lymphoma, but it is difficult to conclusively prove location via simple visual observation (148). Immunological markers and analysis of morphologic criteria is sampled cells are more useful 
for diagnosis (149-151). The immunophenotypes of murine lymphomas often closely resemble those of their human counterparts, despite the fact that a direct human analog of thymic lymphoma does not exist (151).

Since its first description in 1953 by Kaplan et al., the induction of thymic lymphoma (TL) in mice has been extensively studied as a model radiation-induced cancer (142). C57BL substrains, BALB/c and NSF mice are all susceptible to RI-TL (153). Table 2 summarises the induction methods and details of the thymic lymphoma models described below.

\section{C57BL mouse}

C57BL mice, developed in 1921, are one of the most widely used mouse strains in the laboratory. They are derived from a simple cross between female 57 and male 52 of the same Miss Abbie Lanthrop stock. Spontaneous leukemia develops in almost $7 \%$ of C57BL/6 mice (154).

The induction of thymic lymphomas in mice by radiation has been accomplished for many years. Sacher and Brues (155) were able to induce thymic lymphomas with X-irradiation as early as 1949 . In 1952, Kaplan et al. published a seminal paper identifying the optimal dose fractionation period for TL induction. Irradiating C57BL mice just four times at weekly intervals results in $93 \%$ disease penetrance within roughly 250 days of the initial irradiation. When taking into account all of Kaplan's fractionation experiments, even those with lower degrees of penetrance, female C57BL mice are significantly more susceptible in developing thymic lymphoma, with $58 \%$ of females dying of lymphomas versus $47 \%$ of males. TL can also be induced in many substrains with similar frequencies and induction periods, including C57BL/6, C57BL/10 and C57BL/Ka (156-158). The primary sites of metastasis in most murine lymphoma cases are the lungs and peripheral lymph nodes (159).

The presence of MEL-14 ${ }^{\text {hi }}$ (lymphocyte homing receptor), $\mathrm{H}-2 \mathrm{~K}^{\mathrm{hi}}$ (histocompatibility antigen) and $\mathrm{IL}_{-}-2 \mathrm{R}^{+}$(interleukin 2 receptor) surface markers on thymus cortical cells is often a hallmark of nascent lymphoma development. In a healthy adult thymus, less than $3 \%$ of the cells in the cortex express these surface antigens (160-162). Most TL tumors also bear the T-lymphocyte specific antigens Thy-1, Lyt-1 and Lyt-2 $(163,164)$.

In C57/BL mice, the most commonly detected chromosomal abnormality in IR-induced thymic lymphomas is trisomy 15 , seen in $65-71 \%$ of cases $(165,166)$. Duplication of a chromosome 15 leads to a third copy of the oncogene myc $(167,168)$. This aneuploidy has a human parallel, making it highly relevant to human disease progression. In nearly all Burkitt's lymphoma (BL) cases, a translocation between myc's home region and an immunoglobin regulatory region lead to similar increased protein expression. $M y c$ is one of the best known oncogenes; as a transcription factor downregulating apoptosis and upregulating mitosis, its dysregulation has been observed in many cancers besides BL (169). N-ras or K-ras activation is another common oncogene to be activated, reported in just over $50 \%$ of RI-TL cases in the C57BL/6J strain $(161,170)$. Inactivation of tumor suppressor $p 53$ does not seem to be a hallmark of this model's RI-TL progression, although transgenic p53 knockout mice do exhibit higher frequency of RI-TL $(168,171)$.

\section{$\mathrm{BALB} / \mathrm{c}$ mouse}

BALB mice were originally bred by Bagg in 1913. In 1932 Snell expanded the strain and added the ' $c$ ' appellation to reflect their homozygous 'color' locus (172). BALB/c mice are sensitive to radiation-induced lethality, but have not been shown to develop RI lymphatic leukemia. Radiosensitivity of the BALB/c strain is at least partially due to low levels of DNA-PKcs expression, leading to diminished double-strand break repair capacity (173).

However, thymic lymphoma can be readily induced according to the methodology introduced by Kaplan et al. Just as in C57/BL6 mice, 1.7 Gy of fractionated radiation beginning at 4 weeks of age induces this cancer in $86 \%$ of males and $77 \%$ of females, with a mean latency of about 5 months. Although their induced rate is lower, only females spontaneously develop lymphoma in $5.5 \%$ of animals $(148,153)$.

Most studies of lymphomagenesis mechanisms were conducted in either C57BL/6 and its substrains, or in hybrid models comprised of a $\mathrm{BALB} / \mathrm{c}$ parent mated to a radiation-induced lymphoma-resistant strain. More recently, inbred BALB/c mice have been used in studies investigating the role of microRNAs (miRNA) in radiation-induced lymphomagenesis. Liu et al. have concluded that the expression of the tumor suppressor gene Big- $h 3$ is downregulated while miR-21 is upregulated in RI-TL. It is likely that miR-21 suppresses Big- $h 3$ expression by binding to specific target sequences in the $3^{\prime}$ untranslated region of the mRNA (a 3'UTR dependent manner) (174,175).

\section{NFS mouse}

Inbred NFS mice were derived from outbred NIH Swiss-Webster mice introduced to Japan in 1972 . The strain is maintained by sibling mating. It is currently referred to as either NFS or NIH Swiss/S (176).

In NFS mice, induction of thymic lymphoma is performed with four weekly irradiations of 1.7 Gy beginning at 1 month of age, much like induction in BALB/c and C57BL mice. In this strain, males and females have nearly identical susceptibility rates. The latency period, thought, is longer in males, at 208 days versus 167 in females. Spontaneous thymic lymphoma occurs in roughly $10 \%$ of mice by 600 days of age (176). The incidence of IR-TL can be reduced by performing a thymectomy prior to irradation. Completing this procedure before irradiating increases the incidence of nonthymic lymphomas and leukemias, leading to alternative cancers in $67 \%$ of treated mice. This athymic induction potentially provides a murine

Table 2. Induction of thymic lymphoma in mice with low-LET ionising radiation

\begin{tabular}{|c|c|c|c|c|c|c|c|c|c|}
\hline Malignancy & Mouse strain & Age & Sex & Dosage & Fractionation & Latency & $\begin{array}{l}\text { spontaneous } \\
\text { frequency }\end{array}$ & $\begin{array}{l}\text { Induced } \\
\text { frequency }\end{array}$ & Ref. \\
\hline Thymic Lymphoma & $\begin{array}{l}\text { C57BL (C57BL/6, } \\
\text { C57BL/6J) }\end{array}$ & 4-6 weeks & Male, Female & $\sim 1.7$ Gy & $\begin{array}{l}4 \times \text { once } \\
\text { weekly }\end{array}$ & 3-6 months & $<1 \%$ & $>90 \%$ & $(159)$ \\
\hline Thymic Lymphoma & $\begin{array}{l}\mathrm{BALB} / \mathrm{c}(\mathrm{BALB} / \\
\mathrm{cHeA})\end{array}$ & 4 weeks & Male, Female & $\sim 1.7$ Gy & $\begin{array}{l}4 \times \text { once } \\
\text { weekly }\end{array}$ & $\begin{array}{l}2.5- \\
9.5 \text { months }\end{array}$ & $\begin{array}{l}5-6 \% \text { females; } \\
0 \% \text { males }\end{array}$ & $\begin{array}{l}77 \% \text { (Females) } \\
86 \% \text { (Males) }\end{array}$ & $(148,153)$ \\
\hline Thymic Lymphoma & NFS & 4 weeks & Male, Female & $\sim 1.7 \mathrm{~Gy}$ & $\begin{array}{l}4 \times \text { once } \\
\text { weekly }\end{array}$ & 3-6 months & $\begin{array}{l}>1 \% \text { within } \\
12 \text { months }\end{array}$ & $\begin{array}{l}90 \% \text { (females) } \\
89 \% \text { (males) }\end{array}$ & $(176,177)$ \\
\hline
\end{tabular}


lymphoma model more in line with human lymphomagenesis by eliminating the distinctly murine thymic lymphoma. In athymic animals, the latency period for hematopoietic malignancies lasted up to 10 months following IR, 2 months longer than the equivalent TL induction period. These nonthymic lymphomas are most likely to be of B-cell origin, and can be predominantly found in the spleen or mesenteric lymph nodes (177).

\section{TL-associated molecular pathologies}

In thymic lymphoma research, hybrid models are often used over inbred strains due to simpler detection of underlying molecular pathologies. Commonly used hybrids include $(\mathrm{C} 57 \mathrm{BL} / 6 \mathrm{~J} \times \mathrm{BALB} / \mathrm{c})$ $\mathrm{F}_{1}, \mathrm{~B} 6 \mathrm{C} 3 \mathrm{~F} 1(\mathrm{C} 57 \mathrm{BL} / 6 \mathrm{~J} \times \mathrm{C} 3 \mathrm{H}) \mathrm{F}_{1}, \mathrm{C} 3 \mathrm{~B} 6 \mathrm{~F} 1(\mathrm{C} 3 \mathrm{H} \times \mathrm{C} 57 \mathrm{BL} / 6) \mathrm{F}_{1}$, $(\mathrm{BALB} / \mathrm{c} \times \mathrm{MSM}) \mathrm{F}_{1}(178),(\mathrm{C} 57 \mathrm{BL} / 6 \mathrm{~J} \times \mathrm{RF} / \mathrm{J}) \mathrm{F}_{1}(179),(\mathrm{C} 57 \mathrm{BL} / 6 \mathrm{~J} \times$ $\mathrm{DBA}) \mathrm{F}_{1}$ and $\mathrm{CBA} / \mathrm{H} \times \mathrm{C} 57 \mathrm{BL} / 6(180,181)$ as well as the $\mathrm{CXS}$ series of recombinant inbred strains derived from TL-susceptible BALB/ cHeA and TL-resistant STS/A (148). As one might expect, when inducing thymic lymphoma in hybrids between strains with low susceptibilities and those with high susceptibilities, like BALB/c $\times$ MSM, RI-TL frequencies usually lie between those of the parental strains. These particular hybrids will require higher radiation doses to be used during their four weekly fractions when compared to the TL-susceptible strains discussed above, such as the use of $2.5 \mathrm{~Gy}$ rather than 1.7 Gy (178). Studies involving hybrid mice have elucidated the importance of tumor suppressor inactivation in TL progression, with such genes as Ikaros/Znf1a1 (182,183), Bcl11b/Rit1 (184), p73 (185), p19/ARF (186), p15/INK4b(Cdkn2b) and p16/ INK4a(Cdkn2a) (187) commonly deleted or suppressed in radiation-induced lymphomagenesis. Transgenic expression of Notch1 in murine lymphocytes also induces lymphomagenesis (188). As with any cancer, the combination of tumor suppressor inactivation with oncogene activation drastically increases progression. Notch1 activation coupled with inactivation of Notch2, overexpression of $c-M y c$ and defective $Z n f n 1$ a1/Ikaros binding has been reported in $81.25 \%$ of RI-TLs, suggesting their molecular collaboration in the lymphomagenesis process (189). Hybrid experiments also confirm the roles of the common chromosome abnormalities of chromosomes 4, 11 and 12, although such aberrations do not appear ubiquitously in all hybrids. BALB/C $\times$ MSM does not often show LOH on chromosome 4, while the same event is commonly observed in C57BL/6 $\times$ RF/J hybrids (181). Observations like this underscore that genetically inherited predisposition for damaging events to occur at certain gene loci plays an important role in the differences in disease susceptibility and molecular pathology between strains. Saito et al report multiple susceptibility loci, pointing to areas near D4Mit12 on chromosome 4, D2Mit15 on chromosome 2 and D 5 Mit15 on chromosome 5 (178). Additional, sex-dependent susceptibility loci have been identified by Piskorowska and colleagues on chromosome 10 (D10Mit134), and chromosome 12 (D12Mit52I) (190).

The $\mathrm{C} 57 \mathrm{BL} / 6$ and $\mathrm{C} 3 \mathrm{H}$ hybrid strains $\mathrm{C} 3 \mathrm{~B} 6 \mathrm{~F} 1$ and $\mathrm{B} 6 \mathrm{C} 3 \mathrm{~F} 1$ present similar chromosome aberrations, exhibiting copy-number reduction and allelic loss at Ikaros and $B c l 1 b$, but not at $C d k n 2 a l$ $C d k 2 b$ and Pten loci, when compared to their parental strains. Alterations of Ikaros and $B c l 1 b$ are usually due to multilocus deletions, while $C d k n 2 a / C d k 2 b$ and Pten show uniparental disomy. In this strain Ikaros appears to be lost first, followed by the loss of Bcl11l at a later time. This pattern contrasts with that observed in $\mathrm{BALB} / \mathrm{c} \times \mathrm{MSM}$ hybrids, where the order is reversed (166). In C57BL/6 and C3H hybrids rearrangements in Tcra (T-Cell Receptor Alpha) are more common than Tcrb (T-Cell Receptor Beta) rearrangements, although both aberrations are observed Tcrb is more strictly regulated than Tcra, so this disparity is to be expected, but the fact that Tcrb allelic loss is observed suggests that increased aberrant $\mathrm{V}(\mathrm{D}) \mathrm{J}$ rearrangement or increases in illegitimate $\mathrm{V}(\mathrm{D}) \mathrm{J}$ recombination may be important events in IR-induced lymphomagenesis. Divergence in the rates of these particular events may be other factors responsible for differences in susceptibility to RI-TL between strains (166). V(D)J recombination deficiencies are also associated with intragenic deletions in Bcl11b and Notch1. These phenomena have been observed in human lymphoid malignancies as well (191-193).

The idea that the major contribution of radiation to IR-TL is by the indirect mechanism of inducing genomic instability was expanded upon by Kominami and Niwa (194). Their hypothesis suggests that the main result of fractionated total body irradiation is widespread apoptosis in the thymus gland, rather than minor, mutation inducing damage to the larger population of cells. The high casualty rate leaves a void in that cell niche, stimulating differentiation arrest and population regeneration by surviving thymocytes. The replicative stress of this event both reduces replicative fidelity and crafts a progrowth environment for those cells possessing tumorigenic potential (157,195-197). The observation that transplantation or intravenous infusion of unirradiated donor marrow into the irradiated host reduces subsequent lymphomagenesis is consistent with this model. By restoring the thymic microenvironment, the clonal expansion of irradiated T-cell precursors is prevented. Shielding the bone marrow of the irradiated host protects against RI-TL through the same microenvironment-preserving mechanism. Inversely, the transplantation of an unirradiated thymus into an irradiated animal leads to the development of full TL, again suggesting that the replicative stress is most responsible for lymphoma progression rather than direct radiation damage (196,198-200). Muto and colleagues demonstrated that intrathymic and intraperitoneal injections of thymocytes from donors irradiated 4 months previously also resulted in T-type lymphomas derived from donor cells. However, when donor cells were taken only one month post irradiation, only intrathymic injections developed into donor-type lymphomas in the recipient host. This suggests that the thymus is important in the further promotion of these 'prelymphoma' cells. Injecting bone marrow cells rather than thymocytes failed to induce lymphomas in the recipient, suggesting that the bone marrow is a less likely origin site of this prelymphoma cell (201). Furthermore, subjecting RF mice to thymectomy prior to irradiation drastically reduced the incidence of TL, from $32 \%$ to just $1 \%$ (57). Lymphoma progression, therefore, likely follows the body's attempt to repopulate after massive induction of apoptosis after IR. The importance of apoptosis as a key first step in thymic leukemogenesis is further supported by the finding that manipulation of apoptotic susceptibility in GEM can impair or even accelerate the process $(202,203)$. Mori et al point to the region containing $p r k d c$ as a quantitative trait locus determining susceptibility to both radiation-induced apoptosis and cancer (204). The irradiation of supporting cells and tissues, rather than only thymocytes, plays a critical role in the origination of this malignancy. After catastrophic damage is taken by the thymic microenvironment, it is the thymus' own desperate attempts to stimulate thymocyte repopulation that prime the replicatively stressed cells for development into TL.

The interactions between thymus tissues and hematopoietic progenitors which lead to lymphoma appear to be at least partially mediated by Notch receptors and their ligands (194). Alterations in the management of reactive oxygen species (ROS) that would accompany a state of rapid replication would lead to the accumulation of further pro-lymphomic mutations in repopulating thymocytes 
$(31,205)$. The presence of a variant of $M t f-1$ (metal responsive transcription factor-1), identified in TL-susceptible BALB/c mice by Tamura et al., was linked to both higher proliferation levels of premature thymocytes and higher levels of ROS when compared to RI-TL resistant strains lacking this variant $(206,207)$. MTF-1 is involved in post-radiation signaling pathways regulating intracellular ROS (208).

Although thymic lymphoma itself is not specifically observed in humans, the radiation-induced lymphomagenesis mouse model offers important insight into the progression of related human hematopoietic neoplasias. The Ikaros gene, identified in the RI-TL mouse model, is implicated in human acute lymphoblastic leukemia (ALL), the most common hematopoietic malignancy in children (182,209-212). Tsuji et al. used the RI-TL model to demonstrate the contribution of illegitimate $\mathrm{V}(\mathrm{D}) \mathrm{J}$ recombination to Notch1 5 -deletions, deregulation of which is thought to be involved in the etiology of both B- and T-cell human lymphomagenesis (213). Notch1, a diverse master regulator responsible for a plethora of cellular processes, is itself an important player in both RI-TL and T-cell acute lymphoblastic leukemia (213). PTEN (215) and CDKN2A/ CDKN2B have similarly been proposed as potential oncogenes in human ALL $(216,217)$. EPHA7, inactivated in $100 \%$ of TL in mice, is also inactivated in $95.23 \%$ of human T-cell lymphoblastic leukemia/lymphomas (T-LBL) via loss of heterozygosity, promoter hypermethylation, or a combination of the two (218).

\section{Radiation-induced lung cancer}

Lung carcinoma is the deadliest cancer type in industrialised nations, responsible for over a quarter of all cancer deaths. Smoking remains the single greatest risk factor behind this disease (219). Despite this, lung cancers were one of the first to be linked with radiation exposure because of their high rate of mortality (220). The vast majority of data on the link between radiation exposure and development of lung cancer can be attributed to epidemiology from three groups: underground miners, exposed to internal alpha radiation via radon-222 and radon-220 inhalation; Patients who have undergone radiotherapy patients to treat neoplastic and non-neoplastic malignancies; and Japanese atomic bomb survivors $(4,221,222)$. The latency period after induction from gamma or X-ray exposure is particularly long for lung cancer, taking a minimum of $9-10$ years, with an increased risk persisting in survivors for over 25 years. After correcting for gender based differences in smoking rates, females are considerably more susceptible to radiation-induced lung cancer than males. Adenocarcinoma appears to be the most common type of lung cancer in a population exposed to large amounts of radiation. No correlation exists between age of exposure and development of this malignancy $(4,223,224)$. Travis and colleagues have reported that, in Hodgkin's disease patients treated with total radiation doses of 40Gy or more, a significant increase in all histopathological types of lung cancer can be observed even after controlling for smoking. Incidence of radiotherapy-induced lung cancer in Hodgkin's Disease patients peaks 5-9 years after radiation therapy (225-227). Evidence of the link between lung cancer and irradiation is further supported by studies reporting increased rates of lung cancer in radiation treated breast cancer survivors as well $(228,229)$. One study of such irradiation treated breast cancer patients showed a relative lung cancer risk of 1.5 over 10 years when compared to surgery only controls (230).

Localised radiation exposure, like whole body exposure, can result in health effects with varying degrees of severity. In both mice and humans these consequences include pulmonary fibrosis and carcinogenesis. Whether radiation exposure will result in primarily pulmonary fibrosis or increased cancer risk appears to be a function of dose. Fibrosis occurs when cells are killed outright, so it is actually lower doses of IR that are more likely to cause the initiation of carcinogenesis (220). Williams et al provide an extensive guide for the selection of radiation-induced fibrosis animals models (22). The table below summarises three models of radiation-induced lung cancer, generated by employing both whole body irradiations and targeted thoracic exposures in $\mathrm{C} 3 \mathrm{H}, \mathrm{BALB} / \mathrm{c}$ and $\mathrm{RFM}$ mice.

\section{$\mathrm{C} 3 \mathrm{H}$ mouse}

$\mathrm{C} 3 \mathrm{H} / \mathrm{He}$ mice are moderately sensitive to the induction of lung cancers via IR, and also develop spontaneous lung tumors at a low frequency (231). Multiple regimens are viable in this mouse depending on the goal of the researcher. A single 7.5 Gy irradiation to the thorax followed by three 3 Gy whole body irradiations at 3 month intervals afterward yields the highest induction frequency, at $62 \%$. The great

Table 3. Induction of lung cancer in mice with low-LET ionising radiation

\begin{tabular}{|c|c|c|c|c|c|c|c|c|c|}
\hline Malignancy & Mouse strain & Age & Sex & Dosage & Fractionation & Latency & $\begin{array}{l}\text { Spontaneous } \\
\text { frequency }\end{array}$ & Induced frequency & Ref. \\
\hline Lung Cancer & $\mathrm{C} 3 \mathrm{H}(\mathrm{C} 3 \mathrm{H} / \mathrm{HeSlc})$ & 6 weeks & Male & 7.5 Gy thoracic & $\begin{array}{l}2 \text { doses, } 12-\mathrm{h} \\
\text { interval }\end{array}$ & 12 months & $3.5-9.5 \%$ & $40 \%$ & $(232,233)$ \\
\hline Lung Cancer & RFM (RFM/Un) & 10-12 weeks & Female & 9 Gy thoracic & single & 9 months & $\sim 28 \%$ & $87 \%$ & $(235,236)$ \\
\hline Lung Cancer & $\mathrm{BALB} / \mathrm{c}(\mathrm{BALB} / \mathrm{c} / \mathrm{An})$ & 12 weeks & Female & 2 Gy TBI & single & 12 months & $\sim 12 \%$ & $\sim 37 \%$ & $(237,238)$ \\
\hline
\end{tabular}

Table 4. Induction of breast cancer in mice with low-LET ionising radiation

\begin{tabular}{|c|c|c|c|c|c|c|c|c|c|}
\hline Malignancy & Mouse strain & Age & Sex & Dosage & Fractionation & Latency & $\begin{array}{l}\text { Spontaneous } \\
\text { frequency }\end{array}$ & Induced frequency & Ref. \\
\hline Breast cancer & $\mathrm{BALB} / \mathrm{c}$ & 12 weeks & Female & 2.0 Gy TBI & Single & $\sim 24$ months & $8 \%$ & $22 \%$ & $(237)$ \\
\hline Breast cancer & BALB/c orthograft & 12 weeks & Female & $\begin{array}{l}\text { 1.0 Gy TBI of } \\
\text { donor cells }\end{array}$ & Single & 10 weeks & $<1 \%$ & $\begin{array}{l}\text { Dysplasia } ~ 75 \% \\
\text { Tumors } \sim 25 \% \\
\text { (dependent upon } \\
\text { donor cell } \\
\text { passage) }\end{array}$ & $(271)$ \\
\hline Breast cancer & BALB/c chimera & 12 weeks & Female & $\begin{array}{l}4.0 \text { Gy TBI of } \\
\text { host }\end{array}$ & Single & 6 weeks & $\sim 19 \%$ & $\sim 81 \%$ & (30) \\
\hline
\end{tabular}


expanse of time between exposures, however, makes this model less relevant to researchers trying to closely model a human exposure scenario. Another plan, two 7.5 Gy thoracic irradiations around a 12 hour interval, yields roughly $40 \%$ induction in males exposed at 6 weeks of age, and is generally considered to be more relevant clinically. Mice irradiated in this fashion develop alveologenic adenomas and adenocarcinomas after a latency period of 12 months. Tubular or papillary form tumors are observed only rarely (232). In whole body irradiation dose response studies, Hashimoto and colleagues showed that tumor incidence increased with dose to a peak at 5.0 Gy, but decreased at $10 \mathrm{~Gy}$. This observation demonstrates the competitive dynamics between opposing inductive and suppressive effects of radiation with regards to the initiation of cancer and fibrosis. Comparatively lower doses induce DNA strand breaks, deletions and recombinations that can push a cell into cancer development, but higher doses can kill affected cells outright and lead to their replacement by less cancer-prone fibrotic tissue (233).

Even factors as ostensibly distant as circadian rhythm have measureable effects on induction rates. An irradiation at night is a far more potent inducer of RI-LC in C3H mice than an equivalent daytime dose. In this strain, a full 5 Gy of irradiation during the day is required to match the tumor induction frequency seen with just 1.25 Gy at night (232). This response does not seem to be an artifact of the murine model, as circadian variations have been reported in human cancer therapy responses as well (234). As stated previously, dual thoracic irradiation is the most clinically relevant method of induction for this strain, and also carries the lowest rate of inducing other, obfuscating cancer types along with the lung tumors to be studied (220).

\section{RFM mouse}

Lung adenomas are inducible in both male and female RFM/Un mice exposed to IR at $10-12$ weeks old $(235,236)$. Following a single 9.0 Gy thoracic irradiation, roughly $87 \%$ of females develop lung cancer within 6-9 months, with an average of 1.8 tumors per mouse. Males are slightly more resilient. A dose of 10.0 Gy causes the same malignancy roughly $54 \%$ of the time within 11 months, with a tumor multiplicity of 0.8 tumors per mouse. A potential downside of this strain is its high rate of spontaneous lung carcinogenesis, arising in $28 \%$ of unirradiated females and $32 \%$ of males $(235,236)$.

\section{$\mathrm{BALB} / \mathrm{c}$ mouse}

A single 2.0 Gy whole body irradiation at a dose rate of .35 Gy/ min administered to a 12 -week-old female BALB/c/An mouse results in a $37 \%$ induction rate of lung adenocarcinoma, with an average latency of 12 months. The spontaneous rate of these mice developing this cancer is between 11 and $14 \%$ (237). Fractionation of the 2.0 Gy dose does not increase lung cancer incidence relative to the single irradiation (238).

\section{Lung cancer-associated molecular pathologies}

Though the effects of dose, dose-rate, fractionation and radiation quality on murine lung carcinogenesis have been studied extensively for some time, the mechanisms of lung cancer induction are notoriously difficult to discern in animal models. The underlying molecular and pathophysiological mechanisms remained largely elusive until GEM achieved widespread use. Some molecular mechanisms identified still have yet to be definitively correlated with observed pathologies in inbred strains $(233-238,239)$. A great deal of data, though, was able to be obtained retroactively from massive radiation studies

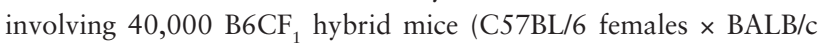
male) at Argonne National Laboratory between 1971 and 1986
(240,241). Genetic material was extracted for PCR-amplification from the paraffin-preserved lung tissues of animals with adenocarcinomas and their controls. A significant percentage of the samples derived from radiation-induced or spontaneous lung adenocarcinomas from this study showed deletions of the tumor suppressor $R b$. Deletion of this gene appeared to cut across all adenocarcinomas regardless of their mechanism of induction, suggesting that its loss is critical to lung cancer progression. No statistically significant differences in $R b$ deletion frequency were observed in adenocarcinomas whether animals received 60 weekly doses of $0.1 \mathrm{~Gy}$, single doses of $5.69 \mathrm{~Gy}$, or were so unfortunate as to develop adenocarcinomas spontaneously. Furthermore, $97 \%$ of samples containing $R b$ deletions also carried $p 53$ deletions, suggesting that mutation of $p 53$ is likely a predominant step in radiation-induced lung carcinogenesis in $\mathrm{B}_{6} \mathrm{CF}_{1}$ mice (241). A separate study on the same preserved tissues also uncovered a high rate of point mutations in the K-ras gene, again regardless of whether the cancer arose spontaneously or after 24 or 60 weekly irradiations (242).

Dysregulation of $p 53, K$-ras and $R b$ are commonly observed in both human and murine lung cancers (243-245). The $p 53$ tumor suppressor is so commonly mutated in cancers of all that it has accumulated a variety of nicknames like 'the guardian of the genome'. Lung cancer is certainly no exception, with its inactivation by either deletion or mutation occuring in $80 \%$ of primary lung tumors (244249). The loss of $p 53$ is associated with poor clinical outcome (243). $R b$ is another tumor suppressor inactivated either directly or indirectly in a wide variety of tumors, including $90 \%$ of human small cell carcinomas $(250,251) . K$-ras is a proto-oncogene involved in cell differentiation, growth and anti-apoptosis, but it also widely modified in many cancers (252). A total of $20-30 \%$ of human lung adenocarcinomas possess a mutation in the RAS gene (253). Activated $K$-ras is also associated with a poor clinical prognosis (254).

Although much of the molecular pathology of lung cancer was teased out of GEM, inbred mice provide a more versatile platform for the testing of therapeutic agents directed against secondary cancers, including those induced or promoted by radiation therapy. Mice genetically engineered to mimic human cancers, such as mice with K-ras knockout of lung adenocarcinoma (23), are useful and sophisticated models for answering specific questions of molecular biology, but are purposefully self-limiting and biased by nature. These models are predisposed to develop only one type of malignancy along a designated progression route. As such, they do not permit the study of alternative mechanisms of carcinogenesis. If radiation-induced lung carcinogenesis, or interventions against it, act outside of precisely pre-programmed initiation and progression pathways, GEM studies are much less relevant. Inbred mice present a more unbiased approach to discovery studies.

\section{Radiation-induced breast cancer}

As with lung cancer, three massive groups are responsible for most epidemiological data on the link between radiation exposure and breast cancer. These three groups are Japanese female survivors of the atomic bomb attacks, females subjected to diagnostic fluoroscopes in Massachusetts tuberculosis sanatoria and women treated for postpartum mastitis in New York $(6,255,256)$. Data from the Japanese atomic bomb cohort demonstrates that breast carcinoma risk increases by a greater extent than all other solid tumor risks upon exposure to IR (4). In the Massachusetts study, females exposed to over a hundred separate instances of diagnostic x-rays were shown to be $80 \%$ more likely to develop breast tumors than controls (255). Radiation therapy is implicated as a causative agent 
in secondary breast cancers, and demonstrate dependency on age at exposure. Up to $35 \%$ of women treated for Hodgkin's disease with radiation therapy early in life developed breast cancer by the age of forty. According to Bhatia and Sankila, the latency period of IR-induced breast cancer is roughly 10 years $(257,258)$. Stovall and colleagues report that an absorbed radiotherapy doses over 1Gy to the contralateral breast during treatment of a primary breast tumor is linked to a high risk of secondary de novo contralateral breast cancer (CBC) (259). Reproductive history is also a factor in CBC risk. Women childless at first cancer diagnosis were more likely to develop CBC after radiotherapy than age-matched mothers (260). According to Boice, women treated with radiation therapy for existing breast cancer can have up to 1.5 times the risk of developing a second, contralateral cancer, especially if irradiated before age 45 . As a total population, about $2.7 \%$ of secondary breast tumors can be attributable to radiation (261).

Ionising radiation is well-established as an etiological agent in both murine and human breast cancer (223,233,262-267). Mammary cancer mouse models are absolutely invaluable to the study of chemotherapeutic interventions and modeling molecular pathologies, despite differences such as differences in precise site of origination and low hormonal dependence frequencies (264). The $\mathrm{BALB} / \mathrm{c}$ mouse is an extensively used model of mammary cancer, which can be induced with either full body irradiation or the implantation of irradiated tissues into syngenic mice (268). As detailed below, much of the radiation sensitivity that contributes to the convenience of the BALB/c model for IR breast cancer induction can be attributed to rather languid PKcs protein activity, which leads to lower levels of NHEJ repair (269). Importantly, this maintains the model's relevance to human breast cancer induction, as the human ortholog of this same gene has a particularly low level of differential expression in human breast tissue (270). Table 4 summarises the most commonly used BALB/c models.

BALB/c whole-body exposure model

Studies in the BALB/c female whole-body irradiation model show an increase in mammary carcinogenesis from a background frequency of around $8 \%$ to about $22 \%$ over the mouse's entire lifetime. This mammary adenocarcinoma induction method consists of irradiating 12 week old females with a total dose of $2.0 \mathrm{~Gy}$, at the dose-rate of $0.35 \mathrm{~Gy} / \mathrm{min}$. Irradiation with the same total dose at the lower dose-rate of $0.083 \mathrm{~Gy} / \mathrm{day}$ results in only half the induction frequency, around $\sim 13 \%$ (237). The high dose rate seems to be key rather than the total dose; even a dose of $0.25 \mathrm{~Gy}$ at $0.35 \mathrm{~Gy} / \mathrm{min}$ is capable of inducing mammary tumors in about $20 \%$ of mice (238). While irradiation increases the incidence of breast adenocarcinomas, it does not decrease disease latency relative to spontaneously arising tumors. Hyperplastic lesions in the mammary ducts are generally detected 12-14 months after IR exposure, prior to appearance of the tumor proper (272). Radiation-induced breast adenocarcinoma sensitivity in the $\mathrm{BALB} / \mathrm{c}$ female has been attributed to polymorphisms of Prkdc, a DNA-dependent protein kinase gene, involved in DNA repair and post-IR cell signaling (269). An unfortunate drawback of this model, despite its simplicity, is its high rate of concurrent ovarian tumor development, detected in over $90 \%$ of autopsied mice (237).

\section{BALB/c syngenic transplant model}

In 1959, a great advance was made in the field of breast cancer biology when DeOme and colleagues introduced a murine orthograft breast cancer model. This model consists of clearing the mammary fat pad from a 3-week-old female virgin mouse and subsequently transplanting a $1 \mathrm{~mm}$ duct fragment from a donor mouse with hyperplastic lesions $(273,274)$. Ethier and Ullrich successfully adopted this model from the original strain into BALB/c mice and used it extensively to demonstrate differences in sensitivity between strains and associated molecular mechanisms $(269,271,275,276)$. Barcellos-Hoff and colleagues employed this model to demonstrate the importance of tissue microenvironment in the breast carcinogenesis process $(277-280)$.

Ethier and Ullrich also employed the 'cell dissociation assay, a combined in vitro/ cell culture model in which 12 week old virgin donor $\mathrm{BALB} / \mathrm{c}$ females are whole body irradiated with a total dose of $1.0 \mathrm{~Gy}$, with mammary tissues removed at $24 \mathrm{~h}$ post-exposure. A single-cell suspension of $10^{4}$ cells from these donor animals is then injected into 3-week-old virgin BALB/c females with cleared mammary fat pads. 10 weeks post procedure, recipient mice are sacrificed and outgrowths removed and analyzed for anomalies in ductal architecture. Normal duct outgrowths contain 2-3 terminal ducts, and are capped by end buds in the fat pad. Abnormal outgrowths, on the other hand, can have 10 or more terminal ducts capped with hyperplastic end buds. These abnormal architectures are classified between Classes I and III, with Class III being most severe $(275,281,282)$.

In another series of experiments, Ullrich and colleagues demonstrated that cells harvested from an irradiated donor, passaged in vitro and finally transplanted into unirradiated recipient mice develop into either dysplasia or adenocarcinomas. The degree of dysplasia exhibited in the host mouse depends upon time of harvesting and number of passages in culture prior to implantation. Cells harvested 52 weeks post-IR tended to generate dysplastic outgrowths in $75 \%$ of mice and develop into full tumors in $25 \%$ of cases. Cells harvested at up to 16 weeks IR only develop into normal outgrowths unless subjected to extensive in vitro passaging. This observation suggests that the irradiated ductal microenvironment plays a critical role in the initiation of oncogenesis. The dysplasia and tumors observed in the host mouse resemble in situ tumorigenesis, complete with leukocyte infiltrations and angiogenesis (272).

\section{$\mathrm{BALB} / \mathrm{c}$ chimeric model}

Barcellos-Hoff and Ravi established a chimeric radiation model in which the fat pads of a BALB/c mouse host are cleared at 3 weeks of age. The same mouse is then whole body irradiated with 4.0 Gy at 10-12 weeks of age (30). Three days later, these hosts receive a transplant of immortalised but non-malignant COMMA-D mouse epithelial cells, derived from midpregnancy BALB/c females (283). Six weeks post-IR the cells injected into irradiated host develop into tumors with $81 \%$ penetrance, compared to only $19 \%$ of cells injected into an unirradiated host. This syngenic model further demonstrates that radiation causes changes in the stromal microenvironment which contribute to carcinogenicity (30). Whole implantation of a $1 \mathrm{~mm}^{3}$ formed duct epithelial fragment acquired from either a wildtype donor or a donor primed for neoplastic development also works as an alternative model to injection of cell suspension (284).

\section{Breast cancer-associated molecular pathologies}

Cell lines harvested from female BALB/C mice 4 weeks (EF42) or 16 weeks (EF137) after 1 Gy whole body irradiation are a common investigative platform for the molecular pathologies of breast cancer tumorigenesis. Cell culture studies point to a number of familiar players in the oncogenic protein scene. Reduced or absent Rb can be detected after 11 passages in EF42 cells, and after only six passages 
in the EF137 line. Mutant p53 is present in $95 \%$ of these cells after 20 passages and even as early as passage 6 in $1-5 \%$ of cultures, supplying more evidence that $p 53$ mutation is an initiating transformation event in preneoplastic cells. Expression of angiogenesis markers can usually be detected after about 20 passages (272). In in vivo transplantation studies, Ethier and Ullrich reported that introducing 10 times the usual amount of cells $\left(10^{5}\right)$ actually decreased both the frequency and severity of observed dysplasia, compared to a standard injection of $10^{4}$ cells $(275,281)$. This suggests that replicative stress may be contributing to faster and more prominent progression into ductal dysplasia.

Barcellos-Hoff and colleagues link the rapid remodeling of the irradiated mammary gland microenvironment to changes in both the extracellular matrix and increases in Transforming growth factor beta (TGF- $\beta$ ) expression (277,285-287). The compensatory expression of this growth factor is likely increased to encourage replacement of cells forced to undergo apoptosis in the original irradiation, but high expression brings with it the dangers of progrowth signaling and replicative stress (284). TGF- $\beta$ is involved in the regulation of a variety of cell processes, including cell cycle control, apoptosis and cell differentiation $(286,288)$. Activation of TGF- $\beta$ as a result of radiation has also been implicated to influence cell fate decisions and DNA-repair kinetics in an ATM-dependent manner $(289,290)$.

Importantly, chimeric models are able to capture prominent features of breast cancers thought to arise following irradiation even though the transplanted epithelium itself has not been irradiated. IR-associated human breast cancer arises from the duct cells and often infiltrates the rest of the breast tissue, a progression similar to that observed in transplantation mouse models (5). Tumors induced from transplanted epithelium that test negative for P53 expression are estrogen receptor (ER) negative as well, much like the phenotype observed in secondary IR derived human breast cancers $(284,291)$. The $R b$ deficiencies observed by Ullrich and Preston in neoplastic duct cells are also often reported in human breast cancer, and correlate with a highly invasive tumor phenotype (292).

\section{Conclusions}

An absolutely ideal radiation-induced carcinogenesis mouse model possesses a low spontaneous background frequency of the desired malignancy, has a short latency period, avoids the co-development of cancers at alternative sites, and produces tumors nearly identical to the corresponding human cancer in terms of onset, progression and underlying pathology. As a perfect model does not exist, researchers are inevitably forced to compromise on some of these features. It is generally more feasible to compromise on features such as cancer latency and induction frequency, as these can be compensated for by study design and sheer subject volume. The most care should be taken to best emulate molecular and pathophysiological features of human radiation-induced malignancies, as these features are key to a model's relevance. No model reflects the human condition completely, however, even on a single factor. The use of mouse models must always be realised as part of a toolkit containing other experimental platforms as well. Radiation-induced secondary cancers can still be difficult to discern from primary tumors in both humans and mouse models. Further research into identifying and differentiating these cancers based on differences in their respective molecular signatures is a difficult challenge, but one that brings great potential reward.

Radiation mitigation, with the aim of reducing cancer risk in irradiated individuals is a developing but promising field. Administration of antioxidants appears to reduce damage from irradiation, likely by quenching ROS generated. The administration of antioxidants generally shows the best effect via protection, not mitigation. However, there is evidence that some medium to long-term radiation-induced injury may come about due to chronic oxidative stress-in which case, the correct application of antioxidants may have a measurable effect in the mitigation window after all (293). Kuefner et al. observed a significant reduction of H2AX foci, markers of DNA damage, upon in vitro preincubation of human lymphocytes with glutathione before irradiation, but this effect did not extend to post-irradiation incubation, nor is it clear whether this effect might carry over to in vivo experimentation (294). As mentioned previously, Amifostine and its active metabolite, WR-1065, have been shown to have some promise differentially protecting healthy tissue over tumor cells during radiotherapy when administered beforehand (20,295). The use of other micronutrients, such as DNA cofactors and selenium, has also been suggested (296). No clear agent stands out yet, however, as the perfect agent to protect against both radiation-induced toxicity and subsequent cancer risk. As with all complex drug/disease interactions, the use of mouse models to determine an effective treatment is an imperative. If a compound can be conclusively shown to effect the myeloid leukemia rates in these establish models, it would have an extraordinary impact on the field of oncology.

The mouse models presented are often a compromise on the background frequencies and rates of induction, but all demonstrate strong molecular and phenotypic correlations to salient features of the human cancers they are meant to represent. These models provide a powerful tool for testing the therapeutic benefit of candidate drugs and other interventions against radiation-induced carcinogenesis.

\section{Acknowledgements}

The authors wish to thank the NIEHS Training Grant in Molecular Toxicology for funding provided to Michael J. Davoren.

Conflict of interest statement: None declared.

\section{References}

1. Howlader N, Noone AM, Krapcho M, et al. (eds). (2012) SEER Cancer Statistics Review, 1975-2009 (Vintage 2009 Populations). National Cancer Institute.

2. Ringborg, U., Bergqvist, D., Brorsson, B., et al. (2003) The Swedish Council on Technology Assessment in Health Care (SBU) systematic overview of radiotherapy for cancer including a prospective survey of radiotherapy practice in Sweden 2001-summary and conclusions. Acta Oncol., 42, 357-365.

3. Prasanna, P. G., Stone, H. B., Wong, R. S., Capala, J., Bernhard, E. J., Vikram, B. and Coleman, C. N. (2012) Normal tissue protection for improving radiotherapy: Where are the Gaps? Transl. Cancer Res., 1, 35-48.

4. Fajardo, L. F., Berthrong, M. and Anderson, R. E. (2001) Radiation Pathology. Oxford University Press, New York.

5. Hall, E. J. and Giaccia, A. J. (2012) Radiobiology for the Radiologist, $7^{\text {th }}$ edn. Wolters Kluwer Health/Lippincott Williams \& Wilkins, Philadelphia.

6. Boice, J. D. Jr and Monson, R. R. (1977) Breast cancer in women after repeated fluoroscopic examinations of the chest. J. Natl. Cancer Inst., 59, 823-832.

7. Mathews, J. D., Forsythe, A. V., Brady, Z., et al. (2013) Cancer risk in 680,000 people exposed to computed tomography scans in childhood or adolescence: data linkage study of 11 million Australians. BMJ, 346, f2360.

8. Pearce, M. S., Salotti, J. A., Little, M. P., et al. (2012) Radiation exposure from CT scans in childhood and subsequent risk of leukaemia and brain tumours: a retrospective cohort study. Lancet, 380, 499-505. 
9. Zelefsky, M. J., Fuks, Z. and Leibel, S. A. (2002) Intensity-modulated radiation therapy for prostate cancer. Semin. Radiat. Oncol., 12, 229-237.

10. de Arruda, F. F., Puri, D. R., Zhung, J., et al. (2006) Intensity-modulated radiation therapy for the treatment of oropharyngeal carcinoma: the Memorial Sloan-Kettering Cancer Center experience. Int. J. Radiat. Oncol. Biol. Phys., 64, 363-373.

11. Chen, J., Morin, O., Aubin, M., Bucci, M. K., Chuang, C. F. and Pouliot, J. (2014) Dose-guided radiation therapy with megavoltage cone-beam CT. Br. J. Radiol, 79, 87-98.

12. Timmerman, R., Paulus, R., Galvin, J., et al. (2010) Stereotactic body radiation therapy for inoperable early stage lung cancer. JAMA, 303, 1070-1076.

13. Hogan, D. E. and Kellison, T. (2002) Nuclear terrorism. Am. J. Med. Sci., 323, 341-349.

14. Stone, H. B., Moulder, J. E., Coleman, C. N., et al. (2004) Models for evaluating agents intended for the prophylaxis, mitigation and treatment of radiation injuries. Report of an NCI Workshop, December 3-4, 2003. Radiat. Res., 162, 711-728.

15. Pellmar, T. C. and Rockwell, S.; Radiological/Nuclear Threat Countermeasures Working Group. (2005) Priority list of research areas for radiological nuclear threat countermeasures. Radiat. Res., 163, 115-123.

16. Moulder, J. E. and Cohen, E. P. (2007) Future strategies for mitigation and treatment of chronic radiation-induced normal tissue injury. Semin. Radiat. Oncol., 17, 141-148.

17. Kim, J. H., Brown, S. L., Kolozsvary, A., Jenrow, K. A., Ryu, S., Rosenblum, M. L. and Carretero, O. A. (2004) Modificatiossn of radiation injury by ramipril, inhibitor of angiotensin-converting enzyme, on optic neuropathy in the rat. Radiat. Res., 161, 137-142.

18. Moulder, J. E., Fish, B. L. and Cohen, E. P. (2003) ACE inhibitors and AII receptor antagonists in the treatment and prevention of bone marrow transplant nephropathy. Curr. Pharm. Des., 9, 737-749.

19. Kim, K., Damoiseaux, R., Norris, A. J., Rivina, L., Bradley, K., Jung, M. E., Gatti, R. A., Schiestl, R. H. and McBride, W. H. (2011) High throughput screening of small molecule libraries for modifiers of radiation responses. Int. J. Radiat. Biol., 87, 839-845.

20. Rubin, P. (2008) Late Effects of Cancer Treatment on Normal Tissues: CURED I, LENT. Springer, Berlin.

21. Ryan, J. L., Krishnan, S., Movsas, B., Coleman, C. N., Vikram, B. and Yoo, S. S. (2011) Decreasing the adverse effects of cancer therapy: an NCI Workshop on the preclinical development of radiation injury mitigators/ protectors. Radiat. Res., 176, 688-691.

22. Williams, J. P., Brown, S. L., Georges, G. E., et al. (2010) Animal models for medical countermeasures to radiation exposure. Radiat. Res., 173, 557-578.

23. Jackson, E. L., Willis, N., Mercer, K., Bronson, R. T., Crowley, D., Montoya, R., Jacks, T. and Tuveson, D. A. (2001) Analysis of lung tumor initiation and progression using conditional expression of oncogenic K-ras. Genes Dev., 15, 3243-3248.

24. Frese, K. K. and Tuveson, D. A. (2007) Maximizing mouse cancer models. Nat. Rev. Cancer, 7, 645-658.

25. Chia, R., Achilli, F., Festing, M. F. and Fisher, E. M. (2005) The origins and uses of mouse outbred stocks. Nat. Genet., 37, 1181-1186.

26. Cui, S., Chesson, C. and Hope, R. (1993) Genetic variation within and between strains of outbred Swiss mice. Lab. Anim., 27, 116-123.

27. Papaioannou, V. E. and Festing, M. F. (1980) Genetic drift in a stock of laboratory mice. Lab. Anim., 14, 11-13.

28. Felton, R. P. and Gaylor, D. W. (1989) Multistrain experiments for screening toxic substances. J. Toxicol. Environ. Health, 26, 399-411.

29. Wu, A. (1992) Physics and dosimetry of the gamma knife. Neurosurg. Clin. N. Am., 3, 35-50.

30. Barcellos-Hoff, M. H. and Ravani, S. A. (2000) Irradiated mammary gland stroma promotes the expression of tumorigenic potential by unirradiated epithelial cells. Cancer Res., 60, 1254-1260.

31. Little, J. B. (2000) Radiation carcinogenesis. Carcinogenesis, 21, 397-404.

32. Fry, R. J., Ley, R. D., Grube, D. and Staffeldt, E. (1982) Studies on the multistage nature of radiation carcinogenesis. Carcinog. Compr. Surv., 7, $155-165$.
33. Kumar, R., Sukumar, S. and Barbacid, M. (1990) Activation of ras oncogenes preceding the onset of neoplasia. Science, 248, 1101-1104.

34. Mori, H., Colman, S. M., Xiao, Z., Ford, A. M., Healy, L. E., Donaldson, C., Hows, J. M., Navarrete, C. and Greaves, M. (2002) Chromosome translocations and covert leukemic clones are generated during normal fetal development. Proc. Natl. Acad. Sci. USA, 99, 8242-8247.

35. March, H. C. (1944) Leukemia in radiologists. Radiology, 43, 275-278.

36. Krebs, C., Rask-Nielsen, H. C. and Wagner, A. (1930) The origin of Lymphosarcomatosis and its relation to other forms of Leucosis in white mice Lymphomatosis infiltrans leucemica et aleucemica. Acta Radiologica, $1-72$.

37. Shore, R. E., Moseson, M., Harley, N. and Pasternack, B. S. (2003) Tumors and other diseases following childhood $\mathrm{x}$-ray treatment for ringworm of the scalp (Tinea capitis). Health Phys., 85, 404-408.

38. Hall, E. J. and Giaccia, A. J. (2006) Radiobiology for the Radiologist, $6^{\text {th }}$ edn. Lippincott Williams \& Wilkins, Philadelphia.

39. Little, M. P., Weiss, H. A., Boice, J. D. Jr, Darby, S. C., Day, N. E. and Muirhead, C. R. (1999) Risks of leukemia in Japanese atomic bomb survivors, in women treated for cervical cancer, and in patients treated for ankylosing spondylitis. Radiat. Res., 152, 280-292.

40. Preston, D. L., Kusumi, S., Tomonaga, M., et al. (1994) Cancer incidence in atomic bomb survivors. Part III. Leukemia, lymphoma and multiple myeloma, 1950-1987. Radiat. Res., 137, S68-S97.

41. Weiss, H. A., Darby, S. C. and Doll, R. (1994) Cancer mortality following X-ray treatment for ankylosing spondylitis. Int. J. Cancer, 59, 327-338.

42. Weiss, H. A., Darby, S. C., Fearn, T. and Doll, R. (1995) Leukemia mortality after X-ray treatment for ankylosing spondylitis. Radiat. Res., 142, $1-11$.

43. Boice, J. D. Jr, Engholm, G., Kleinerman, R. A., et al. (1988) Radiation dose and second cancer risk in patients treated for cancer of the cervix. Radiat. Res., 116, 3-55.

44. Zablotska, L. B., Bazyka, D., Lubin, J. H., et al. (2013) Radiation and the risk of chronic lymphocytic and other leukemias among chornobyl cleanup workers. Environ. Health Perspect., 121, 59-65.

45. Auvinen, A., Seppä, K., Pasanen, K., et al. (2014) Chernobyl fallout and cancer incidence in Finland. Int. J. Cancer, 134, 2253-2263.

46. Noshchenko, A. G., Bondar, O. Y. and Drozdova, V. D. (2010) Radiationinduced leukemia among children aged 0-5 years at the time of the Chernobyl accident. Int. J. Cancer, 127, 412-426.

47. Ivanov, V. K., Tsyb, A. F., Gorsky, A. I., Maksyutov, M. A., Rastopchin, E. M., Konogorov, A. P., Korelo, A. M., Biryukov, A. P. and Matyash, V. A. (1997) Leukaemia and thyroid cancer in emergency workers of the Chernobyl accident: estimation of radiation risks (1986-1995). Radiat. Environ. Biophys., 36, 9-16.

48. Ivanov, V. K., Gorskiǐ, A. I., Tsyb, A. F. and Khaut, S. E. (2003) Incidence of post-Chernobyl leukemia and thyroid cancer in children and adolescents in the Briansk region: evaluation of radiation risks. Vopr. Onkol., 49, 445-449.

49. Ivanov, V. K., Gorski, A. I., Maksioutov, M. A., Vlasov, O. K., Godko, A. M., Tsyb, A. F., Tirmarche, M., Valenty, M. and Verger, P. (2003) Thyroid cancer incidence among adolescents and adults in the Bryansk region of Russia following the Chernobyl accident. Health Phys., 84, 46-60.

50. Preston, D. L., Pierce, D. A., Shimizu, Y., Cullings, H. M., Fujita, S., Funamoto, S. and Kodama, K. (2004) Effect of recent changes in atomic bomb survivor dosimetry on cancer mortality risk estimates. Radiat. Res., 162, 377-389.

51. Little, M. P., Wakeford, R., Tawn, E. J., Bouffler, S. D. and Berrington de Gonzalez, A. (2009) Risks associated with low doses and low dose rates of ionizing radiation: why linearity may be (almost) the best we can do. Radiology, 251, 6-12.

52. Tomonaga, M. (1962) Leukaemia in Nagasaki atomic bomb survivors from 1945 through 1959. Bull. World Health Organ., 26, 619-631.

53. Cardis, E., Gilbert, E. S., Carpenter, L., et al. (1995) Effects of low doses and low dose rates of external ionizing radiation: cancer mortality among nuclear industry workers in three countries. Radiat. Res., 142, 117-132.

54. Richardson, D. B., Wing, S., Schroeder, J., Schmitz-Feuerhake, I. and Hoffmann, W. (2005) Ionizing radiation and chronic lymphocytic leukemia. Environ. Health Perspect., 113, 1-5. 
55. Little, M. P., Wakeford, R. and Kendall, G. M. (2009) Updated estimates of the proportion of childhood leukaemia incidence in Great Britain that may be caused by natural background ionising radiation. J. Radiol. Prot., $29,467-482$.

56. Curtis, R. E., Boice, J. D. Jr, Stovall, M., et al. (1994) Relationship of leukemia risk to radiation dose following cancer of the uterine corpus. J. Natl. Cancer Inst., 86, 1315-1324.

57. Upton, A. C., Wolff, F. F., Furth, J. and Kimball, A. W. (1958) A comparison of the induction of myeloid and lymphoid leukemias in $\mathrm{x}$-radiated RF mice. Cancer Res., 18, 842-848.

58. Wolman, S. R., McMorrow, L. E. and Cohen, M. W. (1982) Animal model of human disease: myelogenous leukemia in the RF mouse. Am. J. Pathol., 107, 280-284.

59. Resnitzky, P., Estrov, Z. and Haran-Ghera, N. (1985) High incidence of acute myeloid leukemia in SJL/J mice after X-irradiation and corticosteroids. Leuk. Res., 9, 1519-1528.

60. Major, I. R. and Mole, R. H. (1978) Myeloid leukaemia in X-ray irradiated CBA mice. Nature, 272, 455-456.

61. Major, I. R. (1979) Induction of myeloid leukaemia by whole-body single exposure of CBA male mice to x-rays. Br. J. Cancer, 40, 903-913.

62. Seki, M., Yoshida, K., Nishimura, M. and Nemoto, K. (1991) Radiationinduced myeloid leukemia in $\mathrm{C} 3 \mathrm{H} / \mathrm{He}$ mice and the effect of prednisolone acetate on leukemogenesis. Radiat. Res., 127, 146-149.

63. Rivina, L., Davoren, M. and Schiestl, R. H. (2014) Radiation-induced myeloid leukemia in murine models. Hum. Genomics, 8, 13.

64. Upton, A. C., Jenkins, V. K. and Conklin, J. W. (1964) Myeloid leukemia in the mouse. Ann. N. Y. Acad. Sci., 114, 189-202.

65. Furth, J., Upton, A. C., Christenberry, K. W., Benedict, W. H. and Moshman, J. (1954) Some late effects in mice of ionizing radiation from an experimental nuclear detonation. Radiology, 63, 562-570.

66. Furth, J. (1946) Recent experimental studies on leukemia. Physiol. Rev., $26,47-76$.

67. Cole, R. K. and Furth, J. (1941) Experimental studies on the genetics of spontaneous leukamia in mice. Cancer Res., 1, 957-965.

68. Ullrich, R. L. and Preston, R. J. (1987) Myeloid leukemia in male RFM mice following irradiation with fission spectrum neutrons or gamma rays. Radiat. Res., 109, 165-170.

69. Upton, A. C., Buffett, R. F., Furth, J. and Doherty, D. G. (1958) Radiationinduced dental death in mice. Radiat. Res., 8, 475-479.

70. Hayata, I., Ishihara, T., Hirashima, K., Sado, T. and Yamagiwa, J. (1979) Partial deletion of chromosome No. 2 in myelocytic leukemias of irradiated C3H/He and RFM mice. J. Natl. Cancer Inst., 63, 843-848.

71. Azumi, J. I. and Sachs, L. (1977) Chromosome mapping of the genes that control differentiation and malignancy in myeloid leukemic cells. Proc. Natl. Acad. Sci. U. S. A., 74, 253-257.

72. Morgan, C. (1980) Hiroshima, Nagasaki and the RERF. Am. J. Pathol., 98, 843-856.

73. Smith, S. M., Le Beau, M. M., Huo, D., Karrison, T., Sobecks, R. M., Anastasi, J., Vardiman, J. W., Rowley, J. D. and Larson, R. A. (2003) Clinicalcytogenetic associations in 306 patients with therapy-related myelodysplasia and myeloid leukemia: the University of Chicago series. Blood, 102, $43-52$.

74. Murphy, E. D. (1963) SJL/J, a new inbred strain of mouse with a high, early incedence of reticulum cell neoplasms. Proc. Am. Assoc. Cancer Res., 464.

75. Dunn, T. B. (1954) Normal and pathologic anatomy of the reticular tissue in laboratory mice, with a classification and discussion of neoplasms. J. Natl. Cancer Inst., 14, 1281-1433.

76. Haran-Ghera, N., Krautghamer, R., Lapidot, T., Peled, A., Dominguez, M. G. and Stanley, E. R. (1997) Increased circulating colony-stimulating factor-1 (CSF-1) in SJL/J mice with radiation-induced acute myeloid leukemia (AML) is associated with autocrine regulation of AML cells by CSF-1. Blood, 89, 2537-2545.

77. Haran-Ghera, N., Kotler, M. and Meshorer, A. (1967) Studies on leukemia development in the SJL/J strain of mice. J. Natl. Cancer Inst., 39, 653-661.

78. Haran-Ghera, N., Resnitzky, P., Krautghamer, R. and Tartakovsky, B. (1992) Multiphase process involved in radiation induced murine AML. Leukemia, 6, 123S-125S.
79. Haran-Ghera, N., Trakhtenbrot, L., Resnitzky, P. and Peled, A. (1989) Preleukemia in experimental leukemogenesis. Haematol. Blood Transfus., $32,243-249$.

80. Trakhtenbrot, L., Krauthgamer, R., Resnitzky, P. and Haran-Ghera, N. (1988) Deletion of chromosome 2 is an early event in the development of radiation-induced myeloid leukemia in SJL/J mice. Leukemia, 2, 545-550.

81. Tartakovsky, B., Goldstein, O., Krautghamer, R. and Haran-Ghera, N. (1993) Low doses of radiation induce systemic production of cytokines: possible contribution to leukemogenesis. Int. J. Cancer, 55, 269-274.

82. Cadman, E. C., Capizzi, R. L. and Bertino, J. R. (1977) Acute nonlymphocytic leukemia: a delayed complication of Hodgkin's disease therapy: analysis of 109 cases. Cancer, 40, 1280-1296.

83. Coleman, C. N., Williams, C. J., Flint, A., Glatstein, E. J., Rosenberg, S. A. and Kaplan, H. S. (1977) Hematologic neoplasia in patients treated for Hodgkin's disease. N. Engl. J. Med., 297, 1249-1252.

84. Pedersen-Bjergaard, J., Philip, P., Pedersen, N. T., Hou-Jensen, K., Svejgaard, A., Jensen, G. and Nissen, N. I. (1984) Acute nonlymphocytic leukemia, preleukemia, and acute myeloproliferative syndrome secondary to treatment of other malignant diseases. II. Bone marrow cytology, cytogenetics, results of HLA typing, response to antileukemic chemotherapy, and survival in a total series of 55 patients. Cancer, 54, 452-462.

85. Scholl, S. M., Bascou, C. H., Mosseri, V., et al. (1994) Circulating levels of colony-stimulating factor 1 as a prognostic indicator in 82 patients with epithelial ovarian cancer. Br. J. Cancer, 69, 342-346.

86. Hakala, A., Kacinski, B. M., Stanley, E. R., Kohorn, E. I., Puistola, U., Risteli, J., Risteli, L., Tomás, C. and Kauppila, A. (1995) Macrophage colony-stimulating factor 1 , a clinically useful tumor marker in endometrial adenocarcinoma: comparison with CA 125 and the aminoterminal propeptide of type III procollagen. Am. J. Obstet. Gynecol., 173, 112-119.

87. Scholl, S. M., Lidereau, R., de la Rochefordière, A., Le-Nir, C. C., Mosseri, V., Noguès, C., Pouillart, P. and Stanley, F. R. (1996) Circulating levels of the macrophage colony stimulating factor CSF-1 in primary and metastatic breast cancer patients. A pilot study. Breast Cancer Res. Treat., 39, 275-283.

88. Toy, E. P., Chambers, J. T., Kacinski, B. M., Flick, M. B. and Chambers, S. K. (2001) The activated macrophage colony-stimulating factor (CSF-1) receptor as a predictor of poor outcome in advanced epithelial ovarian carcinoma. Gynecol. Oncol., 80, 194-200.

89. Festing, M. F. and Blackmore, D. K. (1971) Life span of specified-pathogen-free (MRC category 4) mice and rats. Lab. Anim., 5, 179-192.

90. Yoshida, K., Nemoto, K., Nishimura, M. and Seki, M. (1993) Exacerbating factors of radiation-induced myeloid leukemogenesis. Leuk. Res., 17, 437-440.

91. Yoshida, K., Inoue, T., Nojima, K., Hirabayashi, Y. and Sado, T. (1997) Calorie restriction reduces the incidence of myeloid leukemia induced by a single whole-body radiation in $\mathrm{C} 3 \mathrm{H} / \mathrm{He}$ mice. Proc. Natl. Acad. Sci. USA, 94, 2615-2619.

92. Yoshida, K., Hirabayashi, Y., Watanabe, F., Sado, T. and Inoue, T. (2006) Caloric restriction prevents radiation-induced myeloid leukemia in $\mathrm{C} 3 \mathrm{H} / \mathrm{HeMs}$ mice and inversely increases incidence of tumor-free death: implications in changes in number of hemopoietic progenitor cells. Exp. Hematol., 34, 274-283.

93. Hayata, I., Seki, M., Yoshida, K., Hirashima, K., Sado, T., Yamagiwa, J. and Ishihara, T. (1983) Chromosomal aberrations observed in 52 mouse myeloid leukemias. Cancer Res., 43, 367-373.

94. Ban, N., Kai, M. and Kusama, T. (1997) Chromosome aberrations in bone marrow cells of $\mathrm{C} 3 \mathrm{H} / \mathrm{He}$ mice at an early stage after whole-body irradiation. J. Radiat. Res., 38, 219-231.

95. Coupland, L. A., Jammu, V. and Pidcock, M. E. (2002) Partial deletion of chromosome 1 in a case of acute myelocytic leukemia. Cancer Genet. Cytogenet., 139, 60-62.

96. Finger, L. R., Kagan, J., Christopher, G., Kurtzberg, J., Hershfield, M. S., Nowell, P. C. and Croce, C. M. (1989) Involvement of the TCL5 gene on human chromosome 1 in T-cell leukemia and melanoma. Proc. Natl. Acad. Sci. USA, 86, 5039-5043.

97. Rithidech, K. N., Cronkite, E. P. and Bond, V. P. (1999) Advantages of the CBA mouse in leukemogenesis research. Blood Cells Mol. Dis., 25, $38-45$. 
98. Rithidech, K., Dunn, J. J., Bond, V. P., Gordon, C. R. and Cronkite, E. P. (1999) Characterization of genetic instability in radiation- and benzeneinduced murine acute leukemia. Mutat. Res., 428, 33-39.

99. Mole, R. H. and Major, I. R. (1983) Myeloid leukaemia frequency after protracted exposure to ionizing radiation: experimental confirmation of the flat dose-response found in ankylosing spondylitis after a single treatment course with X-rays. Leuk. Res., 7, 295-300.

100. Smith, I. E., Powles, R., Clink, H. M., Jameson, B., Kay, H. E. and McElwain, T. J. (1977) Early deaths in acute myelogenous leukemia. Cancer, 39, 1710-1714.

101. Rithidech, K. N., Bond, V. P., Cronkite, E. P. and Thompson, M. H. (1993) A specific chromosomal deletion in murine leukemic cells induced by radiation with different qualities. Exp. Hematol., 21, 427-431.

102. Rithidech, K., Dunn, J. J., Roe, B. A., Gordon, C. R. and Cronkite, E. P. (2002) Evidence for two commonly deleted regions on mouse chromosome 2 in gamma ray-induced acute myeloid leukemic cells. Exp. Hematol., 30, 564-570.

103. Rithidech, K., Bond, V. P., Cronkite, E. P., Thompson, M. H. and Bullis, J. E. (1995) Hypermutability of mouse chromosome 2 during the development of x-ray-induced murine myeloid leukemia. Proc. Natl. Acad. Sci. USA, 92, 1152-1156.

104. Bouffler, S. D., Meijne, E. I., Morris, D. J. and Papworth, D. (1997) Chromosome 2 hypersensitivity and clonal development in murine radiation acute myeloid leukaemia. Int. J. Radiat. Biol., 72, 181-189.

105. Cleary, H., Boulton, E. and Plumb, M. (2001) Allelic loss on chromosome 4 (Lyr2/TLSR5) is associated with myeloid, B-lympho-myeloid, and lymphoid (B and T) mouse radiation-induced leukemias. Blood, 98, 1549-1554.

106. Giotopoulos, G., McCormick, C., Cole, C., Zanker, A., Jawad, M., Brown, R. and Plumb, M. (2006) DNA methylation during mouse hemopoietic differentiation and radiation-induced leukemia. Exp. Hematol., 34, 1462-1470.

107. Jawad, M., Giotopoulos, G., Fitch, S., Cole, C., Plumb, M. and Talbot, C. J. (2007) Mouse bone marrow and peripheral blood erythroid cell counts are regulated by different autosomal genetic loci. Blood Cells. Mol. Dis., 38, 69-77.

108. Dekkers, F., Bijwaard, H., Bouffler, S., Ellender, M., Huiskamp, R., Kowalczuk, C., Meijne, E. and Sutmuller, M. (2011) A two-mutation model of radiation-induced acute myeloid leukemia using historical mouse data. Radiat. Environ. Biophys., 50, 37-45.

109. Graves, J. A. (1996) Mammals that break the rules: genetics of marsupials and monotremes. Annu. Rev. Genet., 30, 233-260.

110. Carver, E. A. and Stubbs, L. (1997) Zooming in on the human-mouse comparative map: genome conservation re-examined on a high-resolution scale. Genome Res., 7, 1123-1137.

111. Talpaz, M., Shah, N. P., Kantarjian, H., et al. (2006) Dasatinib in imatinib-resistant Philadelphia chromosome-positive leukemias. N. Engl. J. Med., 354, 2531-2541.

112. Alexander, B. J., Rasko, J. E., Morahan, G. and Cook, W. D. (1995) Gene deletion explains both in vivo and in vitro generated chromosome 2 aberrations associated with murine myeloid leukemia. Leukemia, 9, 2009-2015.

113. Silver, A., Moody, J., Dunford, R., et al. (1999) Molecular mapping of chromosome 2 deletions in murine radiation-induced AML localizes a putative tumor suppressor gene to a $1.0 \mathrm{cM}$ region homologous to human chromosome segment 11p11-12. Genes Chromosomes Cancer, 24, 95-104.

114. Cook, W. D., McCaw, B. J., Herring, C., John, D. L., Foote, S. J., Nutt, S. L. and Adams, J. M. (2004) PU.1 is a suppressor of myeloid leukemia, inactivated in mice by gene deletion and mutation of its DNA binding domain. Blood, 104, 3437-3444.

115. Moreau-Gachelin, F., Tavitian, A. and Tambourin, P. (1988) Spi-1 is a putative oncogene in virally induced murine erythroleukaemias. Nature, 331, 277-280.

116. Scott, E. W., Simon, M. C., Anastasi, J. and Singh, H. (1994) Requirement of transcription factor PU.1 in the development of multiple hematopoietic lineages. Science, 265, 1573-1577.
117. Simon, M. C., Olson, M., Scott, E., Hack, A., Su, G. and Singh, H. (1996) Terminal myeloid gene expression and differentiation requires the transcription factor PU.1. Curr. Top. Microbiol. Immunol., 211, 113-119.

118. McKercher, S. R., Torbett, B. E., Anderson, K. L., et al. (1996) Targeted disruption of the PU.1 gene results in multiple hematopoietic abnormalities. $Е M B O$ J., 15, 5647-5658.

119. Kastner, P. and Chan, S. (2008) PU.1: a crucial and versatile player in hematopoiesis and leukemia. Int. J. Biochem. Cell Biol., 40, 22-27.

120. Joo, M., Park, G. Y., Wright, J. G., Blackwell, T. S., Atchison, M. L. and Christman, J. W. (2004) Transcriptional regulation of the cyclooxygenase-2 gene in macrophages by PU.1. J. Biol. Chem., 279, 6658-6665.

121. Owen, J.A., Punt, J., Stranford, S. A., and Jones, P. P. (2013) Kuby Immunology. WH Freeman, New York.

122. Scott, E. W., Simon, M. C., Anastasi, J. and Singh, H. (1994) Requirement of transcription factor PU.1 in the development of multiple hematopoietic lineages. Science, 265, 1573-1577.

123. Suraweera, N., Meijne, E., Moody, J., et al. (2005) Mutations of the PU.1 Ets domain are specifically associated with murine radiation-induced, but not human therapy-related, acute myeloid leukaemia. Oncogene, 24, 3678-3683.

124. Mueller, B. U., Pabst, T., Osato, M., et al. (2002) Heterozygous PU.1 mutations are associated with acute myeloid leukemia. Blood, 100, 998-1007.

125. Rosenbauer, F., Wagner, K., Kutok, J. L., Iwasaki, H., Le Beau, M. M., Okuno, Y., Akashi, K., Fiering, S. and Tenen, D. G. (2004) Acute myeloid leukemia induced by graded reduction of a lineage-specific transcription factor, PU.1. Nat. Genet., 36, 624-630.

126. Metcalf, D., Dakic, A., Mifsud, S., Di Rago, L., Wu, L. and Nutt, S. (2006) Inactivation of PU.1 in adult mice leads to the development of myeloid leukemia. Proc. Natl. Acad. Sci. U. S. A., 103, 1486-1491.

127. Walter, M. J., Park, J. S., Ries, R. E., Lau, S. K., McLellan, M., Jaeger, S., Wilson, R. K., Mardis, E. R. and Ley, T. J. (2005) Reduced PU.1 expression causes myeloid progenitor expansion and increased leukemia penetrance in mice expressing PML-RARalpha. Proc. Natl. Acad. Sci. USA, $102,12513-12518$.

128. Hirouchi, T., Takabatake, T., Yoshida, K., Nitta, Y., Nakamura, M., Tanaka, S., Ichinohe, K., Oghiso, Y. and Tanaka, K. (2008) Upregulation of c-myc gene accompanied by PU.1 deficiency in radiation-induced acute myeloid leukemia in mice. Exp. Hematol., 36, 871-885.

129. Peng, Y., Brown, N., Finnon, R., et al. (2009) Radiation leukemogenesis in mice: loss of PU. 1 on chromosome 2 in CBA and C57BL/6 mice after irradiation with $1 \mathrm{GeV} /$ nucleon $56 \mathrm{Fe}$ ions, $\mathrm{X}$ rays or gamma rays. Part I. Experimental observations. Radiat. Res., 171, 474-483.

130. Moreau-Gachelin, F., Wendling, F., Molina, T., Denis, N., Titeux, M., Grimber, G., Briand, P., Vainchenker, W. and Tavitian, A. (1996) Spi-1/ PU.1 transgenic mice develop multistep erythroleukemias. Mol. Cell. Biol., 16, 2453-2463.

131. Steidl, U., Rosenbauer, F., Verhaak, R. G., et al. (2006) Essential role of Jun family transcription factors in PU.1 knockdown-induced leukemic stem cells. Nat. Genet., 38, 1269-1277.

132. Fernando, T. R., Rodriguez-Malave, N. I. and Rao, D. S. (2012) MicroRNAs in B cell development and malignancy. J. Hematol. Oncol., 5, 7.

133. Finnon, R., Brown, N., Moody, J., et al. (2012) Flt3-ITD mutations in a mouse model of radiation-induced acute myeloid leukaemia. Lenkemia, $26,1445-1446$.

134. Plumb, M., Cleary, H. and Wright, E. (1998) Genetic instability in radiation-induced leukaemias: mouse models. Int. J. Radiat. Biol., 74, 711-720.

135. Boulton, E., Cleary, H., Papworth, D. and Plumb, M. (2001) Susceptibility to radiation-induced leukaemia/lymphoma is genetically separable from sensitivity to radiation-induced genomic instability. Int. J. Radiat. Biol., 77, 21-29.

136. Morgan, W. F. (2003) Is there a common mechanism underlying genomic instability, bystander effects and other nontargeted effects of exposure to ionizing radiation? Oncogene, 22, 7094-7099.

137. Busuttil, R. A., Rubio, M., Dollé, M. E., Campisi, J. and Vijg, J. (2003) Oxygen accelerates the accumulation of mutations during the senescence and immortalization of murine cells in culture. Aging Cell, 2, 287-294. 
138. Ban, N. and Kai, M. (2009) Implication of replicative stress-related stem cell ageing in radiation-induced murine leukaemia. Br. J. Cancer, 101, 363-371.

139. Hirouchi, T., Akabane, M., Tanaka, S., Braga-Tanaka, I. 3rd, Todate, A., Ichinohe, K., Oghiso, Y. and Tanaka, K. (2011) Cell surface marker phenotypes and gene expression profiles of murine radiation-induced acute myeloid leukemia stem cells are similar to those of common myeloid progenitors. Radiat. Res., 176, 311-322.

140. Darakhshan, F., Badie, C., Moody, J., et al. (2006) Evidence for complex multigenic inheritance of radiation AML susceptibility in mice revealed using a surrogate phenotypic assay. Carcinogenesis, 27, 311-318.

141. Schottenfeld, D., and Fraumeni, J.F. (2006) Cancer Epidemiology and Prevention, $3^{\text {rd }}$ edn. Oxford University Press, Oxford.

142. Hartge, P. and Smith, M. T. (2007) Environmental and behavioral factors and the risk of non-Hodgkin lymphoma. Cancer Epidemiol. Biomarkers Prev., 16, 367-368.

143. Boice, J. D. Jr. (1992) Radiation and non-Hodgkin's lymphoma. Cancer Res., 52, 5489s-5491s.

144. United Nations. Scientific Committee on the Effects of Atomic Radiation. (2000) Sources and effects of ionizing radiation: United Nations Scientific Committee on the Effects of Atomic Radiation: UNSCEAR 2000 report to the General Assembly, with scientific annexes. United Nations, New York.

145. Adami, H. -O., Hunter, D. J., and Trichopoulos, D. (2002) Textbook of cancer epidemiology. Oxford University Press, Oxford.

146. Richardson, D. B., Sugiyama, H., Wing, S., et al. (2009) Positive associations between ionizing radiation and lymphoma mortality among men. Am. J. Epidemiol., 169, 969-976.

147. Waalkes, M. P. and Ward, J. M. (1994) Carcinogenesis. Raven Press, New York.

148. Okumoto, M., Nishikawa, R., Imai, S. and Hilgers, J. (1990) Genetic analysis of resistance to radiation lymphomagenesis with recombinant inbred strains of mice. Cancer Res., 50, 3848-3850.

149. Pattengale, P. K. and Taylor, C. R. (1983) Experimental models of lymphoproliferative disease. The mouse as a model for human nonHodgkin's lymphomas and related leukemias. Am. J. Pathol., 113, 237-265.

150. Pattengale, P. K. and Frith, C. H. (1983) Immunomorphologic classification of spontaneous lymphoid cell neoplasms occurring in female BALB/c mice. J. Natl. Cancer Inst., 70, 169-179.

151. Pattengale, P., Leder, A., Kuo, A., Stewart, T. and Leder, P. (1986) Lymphohematopoietic and other malignant neoplasms occurring spontaneously in transgenic mice carrying and expressing MTV/myc fusion genes. Curr. Top. Microbiol. Immunol., 132, 9-16.

152. Kaplan, H. S., Brown, M. B. and Paull, J. (1953) Influence of postirradiation thymectomy and of thymic implants on lymphoid tumor incidence in C57BL mice. Cancer Res., 13, 677-680.

153. Okumoto, M., Nishikawa, R., Imai, S. and Hilgers, J. (1989) Resistance of STS/A mice to lymphoma induction by X-irradiation. J. Radiat. Res., 30, 135-139.

154. Meier, H., Myers, D. D. and Huebner, R. J. (1970) Differential effect of a synthetic polyribonucleotide complex on spontaneous and transplanted leukemia in mice. Life Sci. II., 9, 653-659.

155. Sacher, G. A. and Brues A. M. (1949) Analysis of lymphoma induction by $\mathrm{X}$ rays in mice. Cancer Res., 1.

156. Muto, M., Sado, T., Hayata, I., Nagasawa, F., Kamisaku, H. and Kubo, E. (1983) Reconfirmation of indirect induction of radiogenic lymphomas using thymectomized, irradiated B10 mice grafted with neonatal thymuses from Thy 1 congenic donors. Cancer Res., 43, 3822-3827.

157. Boniver, J., Humblet, C., Rongy, A. M., Delvenne, C., Delvenne, P., Greimers, R., Thiry, A., Courtoy, R. and Defresne, M. P. (1990) Cellular aspects of the pathogenesis of radiation-induced thymic lymphomas in C57 BL mice (review). In Vivo, 4, 41-43.

158. Humblet, C., Greimers, R., Boniver, J. and Defrense, M. P. (1997) Stages in the development of radiation-induced thymic lymphomas in $\mathrm{C} 57 \mathrm{BL} /$ Ka mice: preleukemic cells become progressively resistant to the tumor preventing effects of a bone marrow graft. Exp. Hematol., 25, 109-113.
159. Kaplan, H. S. (1952) Radiation-induced lymphoid tumors of mice. Acta Unio Int. Contra Cancrum, 7, 849-859.

160. Reichert, W., Buselmaier, W. and Vogel, F. (1984) Elimination of X-rayinduced chromosomal aberrations in the progeny of female mice. Mutat. Res., 139, 87-94.

161. Newcomb, E. W., Steinberg, J. J. and Pellicer, A. (1988) ras oncogenes and phenotypic staging in N-methylnitrosourea- and gamma-irradiation-induced thymic lymphomas in C57BL/6J mice. Cancer Res., 48, 5514-5521.

162. Amari, N. M. and Meruelo, D. (1987) Murine thymomas induced by fractionated-X-irradiation have specific T-cell receptor rearrangements and characteristics associated with day- 15 to -16 fetal thymocytes. Mol. Cell. Biol., 7, 4159-4168.

163. Hogarth, P. M., Henning, M. M. and McKenzie, I. F. (1982) Alloantigenic phenotype of radiation-induced thymomas in the mouse. J. Natl. Cancer Inst., 69, 619-626.

164. Hogarth, P. M., Edwards, J., McKenzie, I. F., Goding, J. W. and Liew, F. Y. (1982) Monoclonal antibodies to the murine Ly-2.1 cell surface antigen. Immunology, 46, 135-144.

165. McMorrow, L. E., Newcomb, E. W. and Pellicer, A. (1988) Identification of a specific marker chromosome early in tumor development in gammairradiated C57BL/6J mice. Lenkemia, 2, 115-119.

166. Takabatake, T., Kakinuma, S., Hirouchi, T., Nakamura, M. M., Fujikawa, K., Nishimura, M., Oghiso, Y., Shimada, Y. and Tanaka, K. (2008) Analysis of changes in DNA copy number in radiation-induced thymic lymphomas of susceptible C57BL/6, resistant C3H and hybrid F1 Mice. Radiat. Res., 169, 426-436.

167. Sasaki, M. (1982) Current status of cytogenetic studies in animal tumors with special reference to nonrandom chromosome changes. Cancer Genet. Cytogenet., 5, 153-172.

168. Brathwaite, O., Bayona, W. and Newcomb, E. W. (1992) p53 mutations in $\mathrm{C} 57 \mathrm{BL} / 6 \mathrm{~J}$ murine thymic lymphomas induced by gamma-irradiation and N-methylnitrosourea. Cancer Res., 52, 3791-3795.

169. Tomita, N. (2011) BCL2 and MYC dual-hit lymphoma/leukemia. J. Clin. Exp. Hematopathol., 51, 7-12.

170. Newcomb, E. W., Corominas, M., Bayona, W. and Pellicer, A. (1989) Multistage carcinogenesis in murine thymocytes: involvement of oncogenes, chromosomal imbalances and T cell growth factor receptor. Anticancer Res., 9, 1407-1415.

171. Mao, J. H., Wu, D., Perez-Losada, J., Nagase, H., DelRosario, R. and Balmain, A. (2003) Genetic interactions between Pten and p53 in radiation-induced lymphoma development. Oncogene, 22, 8379-8385.

172. Potter, M. (1985) History of the BALB/c family. In The BALB/c Mouse. Springer Berlin, Heidelberg, pp. 1-5.

173. Okayasu, R., Suetomi, K., Yu, Y., Silver, A., Bedford, J. S., Cox, R. and Ullrich, R. L. (2000) A deficiency in DNA repair and DNA-PKcs expression in the radiosensitive BALB/c mouse. Cancer Res., 60, 4342-4345.

174. Liu, C., Li, B., Cheng, Y., et al. (2011) MiR-21 plays an important role in radiation induced carcinogenesis in $\mathrm{BALB} / \mathrm{c}$ mice by directly targeting the tumor suppressor gene Big-h3. Int. J. Biol. Sci., 7, 347-363.

175. Lewis, B. P., Shih, I. H., Jones-Rhoades, M. W., Bartel, D. P. and Burge, C. B. (2003) Prediction of mammalian microRNA targets. Cell, 115, 787-798.

176. Okumoto, M., Nishikawa, R., Takamori, Y., Iwai, Y., Iwai, M. and Tsubura, Y. (1985) Endogenous type-C viral expression during lymphoma development in irradiated NFS mice. Radiat. Res., 104, 153-165.

177. Mori, N. and Takamori, Y. (1990) Development of nonthymic lymphomas in thymectomized NFS mice exposed to split-dose X-irradiation. J. Radiat. Res., 31, 389-395.

178. Saito, Y., Ochiai, Y., Kodama, Y., et al. (2001) Genetic loci controlling susceptibility to gamma-ray-induced thymic lymphoma. Oncogene, 20, 5243-5247.

179. Santos, J., Pérez de Castro, I., Herranz, M., Pellicer, A. and FernándezPiqueras, J. (1996) Allelic losses on chromosome 4 suggest the existence of a candidate tumor suppressor gene region of about $0.6 \mathrm{cM}$ in gammaradiation-induced mouse primary thymic lymphomas. Oncogene, 12, 669-676. 
180. Cleary, H. J., Boulton, E. and Plumb, M. (1999) Allelic loss and promoter hypermethylation of the $\mathrm{p} 15 \mathrm{INK} 4 \mathrm{~b}$ gene features in mouse radiation-induced lymphoid - but not myeloid - leukaemias. Leukemia, 13, 2049-2052.

181. Cleary, H. J., Wright, E. and Plumb, M. (1999) Specificity of loss of heterozygosity in radiation-induced mouse myeloid and lymphoid leukaemias. Int. J. Radiat. Biol., 75, 1223-1230.

182. Okano, H., Saito, Y., Miyazawa, T., et al. (1999) Homozygous deletions and point mutations of the Ikaros gene in gamma-ray-induced mouse thymic lymphomas. Oncogene, 18, 6677-6683.

183. Shimada, Y., Nishimura, M., Kakinuma, S., Okumoto, M., Shiroishi, T., Clifton, K. H. and Wakana, S. (2000) Radiation-associated loss of heterozygosity at the Znfn1a1 (Ikaros) locus on chromosome 11 in murine thymic lymphomas. Radiat. Res., 154, 293-300.

184. Shinbo, T., Matsuki, A., Matsumoto, Y., Kosugi, S., Takahashi, Y., Niwa, O. and Kominami, R. (1999) Allelic loss mapping and physical delineation of a region harboring a putative thymic lymphoma suppressor gene on mouse chromosome 12. Oncogene, 18, 4131-4136.

185. Herranz, M., Santos, J., Salido, E., Fernández-Piqueras, J. and Serrano, M. (1999) Mouse p73 gene maps to the distal part of chromosome 4 and might be involved in the progression of gamma-radiation-induced T-cell lymphomas. Cancer Res., 59, 2068-2071.

186. Meléndez, B., Malumbres, M., Pérez de Castro, I., Santos, J., Pellicer, A. and Fernández-Piqueras, J. (2000) Characterization of the murine p19(ARF) promoter $\mathrm{CpG}$ island and its methylation pattern in primary lymphomas. Carcinogenesis, 21, 817-821.

187. Malumbres, M., Pérez de Castro, I., Santos, J., Fernández Piqueras, J. and Pellicer, A. (1999) Hypermethylation of the cell cycle inhibitor p15INK4b 3'-untranslated region interferes with its transcriptional regulation in primary lymphomas. Oncogene, 18, 385-396.

188. Pear, W. S., Aster, J. C., Scott, M. L., Hasserjian, R. P., Soffer, B., Sklar, J. and Baltimore, D. (1996) Exclusive development of T cell neoplasms in mice transplanted with bone marrow expressing activated Notch alleles. J. Exp. Med., 183, 2283-2291.

189. López-Nieva, P., Santos, J. and Fernández-Piqueras, J. (2004) Defective expression of Notch1 and Notch2 in connection to alterations of c-Myc and Ikaros in gamma-radiation-induced mouse thymic lymphomas. Carcinogenesis, 25, 1299-1304.

190. Piskorowska, J., Gajewska, M., Szymańska, H., et al. (2011) Susceptibility loci and chromosomal abnormalities in radiation induced hematopoietic neoplasms in mice. J. Radiat. Res., 52, 147-158.

191. Davila, M., Foster, S., Kelsoe, G. and Yang, K. (2001) A role for secondary $\mathrm{V}(\mathrm{D}) \mathrm{J}$ recombination in oncogenic chromosomal translocations? Adv. Cancer Res., 81, 61-92.

192. Marculescu, R., Le, T., Böcskör, S., Mitterbauer, G., Chott, A., Mannhalter, C., Jaeger, U. and Nadel, B. (2002) Alternative end-joining in follicular lymphomas' t(14;18) translocation. Leukemia, 16, 120-126.

193. Marculescu, R., Le, T., Simon, P., Jaeger, U. and Nadel, B. (2002) $\mathrm{V}(\mathrm{D}) \mathrm{J}$-mediated translocations in lymphoid neoplasms: a functional assessment of genomic instability by cryptic sites. J. Exp. Med., 195, $85-98$

194. Kominami, R. and Niwa, O. (2006) Radiation carcinogenesis in mouse thymic lymphomas. Cancer Sci., 97, 575-581.

195. Kaplan, H. S. (1964) The role of radiation on experimental leukemogenesis. Natl. Cancer Inst. Monogr., 14, 207-220.

196. Sado, T., Kamisaku, H. and Kubo, E. (1991) Bone marrow-thymus interactions during thymic lymphomagenesis induced by fractionated radiation exposure in B10 mice: analysis using bone marrow transplantation between Thy 1 congenic mice. J. Radiat. Res., 32, 168-180.

197. Boniver, J., Humblet, C., Rongy, A. M., Delvenne, C., Delvenne, P., Greimers, R., Thiry, A., Courtoy, R. and Defresne, M. P. (1990) Cellular events in radiation-induced lymphomagenesis. Int. J. Radiat. Biol., 57, 693-698.

198. Kaplan, H. S., Hirsch, B. B. and Brown, M. B. (1956) Indirect induction of lymphomas in irradiated mice. IV. Genetic evidence of the origin of the tumor cells from the thymic grafts. Cancer Res., 16, 434-436.

199. Kaplan, H. S., Carnes, W. H., Brown, M. B. and Hirsch, B. B. (1956) Indirect induction of lymphomas in irradiated mice. I. Tumor incidence and morphology in mice bearing nonirradiated thymic grafts. Cancer Res., 16, 422-425.

200. Kaplan, H. S., Brown, M. B., Hirsch, B. B. and Carnes, W. H. (1956) Indirect induction of lymphomas in irradiated mice. II. Factor of irradiation of the host. Cancer Res., 16, 426-428.

201. Muto, M., Kubo, E. and Sado, T. (1987) Development of prelymphoma cells committed to thymic lymphomas during radiation-induced thymic lymphomagenesis in B10 mice. Cancer Res., 47, 3469-3472.

202. Michalak, E. M., Vandenberg, C. J., Delbridge, A. R., Wu, L., Scott, C. L., Adams, J. M. and Strasser, A. (2010) Apoptosis-promoted tumorigenesis: gamma-irradiation-induced thymic lymphomagenesis requires Puma-driven leukocyte death. Genes Dev., 24, 1608-1613.

203. Labi, V., Erlacher, M., Krumschnabel, G., Manzl, C., Tzankov, A., Pinon, J., Egle, A. and Villunger, A. (2010) Apoptosis of leukocytes triggered by acute DNA damage promotes lymphoma formation. Genes Dev., 24, 1602-1607.

204. Mori, N., Matsumoto, Y., Okumoto, M., Suzuki, N. and Yamate, J. (2001) Variations in Prkdc encoding the catalytic subunit of DNAdependent protein kinase (DNA-PKcs) and susceptibility to radiationinduced apoptosis and lymphomagenesis. Oncogene, 20, 3609-3619.

205. Redpath, J. L. and Gutierrez, M. (2001) Kinetics of induction of reactive oxygen species during the post-irradiation expression of neoplastic transformation in vitro. Int. J. Radiat. Biol., 77, 1081-1085.

206. Tamura, Y., Maruyama, M., Mishima, Y., et al. (2005) Predisposition to mouse thymic lymphomas in response to ionizing radiation depends on variant alleles encoding metal-responsive transcription factor-1 (Mtf-1). Oncogene, 24, 399-406.

207. Maruyama, M., Yamamoto, T., Kohara, Y., Katsuragi, Y., Mishima, Y., Aoyagi, Y. and Kominami, R. (2007) Mtf-1 lymphoma-susceptibility locus affects retention of large thymocytes with high ROS levels in mice after gamma-irradiation. Biochem. Biophys. Res. Commun., 354, 209-215.

208. Lichtlen, P., Wang, Y., Belser, T., Georgiev, O., Certa, U., Sack, R. and Schaffner, W. (2001) Target gene search for the metal-responsive transcription factor MTF-1. Nucleic Acids Res., 29, 1514-1523.

209. Sun, L., Goodman, P. A., Wood, C. M., et al. (1999) Expression of aberrantly spliced oncogenic ikaros isoforms in childhood acute lymphoblastic leukemia. J. Clin. Oncol., 17, 3753-3766.

210. Sun, L., Crotty, M. L., Sensel, M., et al. (1999) Expression of dominantnegative Ikaros isoforms in T-cell acute lymphoblastic leukemia. Clin. Cancer Res., 5, 2112-2120.

211. Ruiz, A., Jiang, J., Kempski, H. and Brady, H. J. (2004) Overexpression of the Ikaros 6 isoform is restricted to $t(4 ; 11)$ acute lymphoblastic leukaemia in children and infants and has a role in B-cell survival. $\mathrm{Br}$. J. Haematol., 125, 31-37.

212. Mullighan, C. G., Miller, C. B., Radtke, I., et al. (2008) BCR-ABL1 lymphoblastic leukaemia is characterized by the deletion of Ikaros. Nature, 453, 110-114.

213. Tsuji, H., Ishii-Ohba, H., Katsube, T., Ukai, H., Aizawa, S., Doi, M., Hioki, K. and Ogiu, T. (2004) Involvement of illegitimate V(D)J recombination or microhomology-mediated nonhomologous end-joining in the formation of intragenic deletions of the Notch1 gene in mouse thymic lymphomas. Cancer Res., 64, 8882-8890.

214. Weng, A. P., Ferrando, A. A., Lee, W., Morris, J. P. 4th, Silverman, L. B., Sanchez-Irizarry, C., Blacklow, S. C., Look, A. T. and Aster, J. C. (2004) Activating mutations of NOTCH1 in human T cell acute lymphoblastic leukemia. Science, 306, 269-271.

215. Zuurbier, L., Petricoin, E. F. $3^{\text {rd }}$, Vuerhard, M. J., et al. (2012) The significance of PTEN and AKT aberrations in pediatric T-cell acute lymphoblastic leukemia. Haematologica, 97, 1405-1413.

216. Mulligan, C. S., Best, O. G. and Mulligan, S. P.; Chronic Lymphocytic Leukaemia Australian Research Consortium. (2009) The precursor of chronic lymphocytic leukemia. N. Engl. J. Med., 360, 2575.

217. Okuda, T., Shurtleff, S. A., Valentine, M. B., et al. (1995) Frequent deletion of p16INK4a/MTS1 and p15INK4b/MTS2 in pediatric acute lymphoblastic leukemia. Blood, 85, 2321-2330.

218. López-Nieva, P., Vaquero, C., Fernández-Navarro, P., González-Sánchez, L., Villa-Morales, M., Santos, J., Esteller, M. and Fernández-Piqueras, J. 
(2012) EPHA7, a new target gene for 6q deletion in T-cell lymphoblastic lymphomas. Carcinogenesis, 33, 452-458.

219. Carbone, D. (1992) Smoking and cancer. Am. J. Med., 93, 13S-17S.

220. Coggle, J. E., Lambert, B. E. and Moores, S. R. (1986) Radiation effects in the lung. Environ. Health Perspect., 70, 261-291.

221. Griem, M. L., Kleinerman, R. A., Boice, J. D. Jr, Stovall, M., Shefner, D. and Lubin, J. H. (1994) Cancer following radiotherapy for peptic ulcer. J. Natl. Cancer Inst., 86, 842-849.

222. Darby, S. C., Doll, R., Gill, S. K. and Smith, P. G. (1987) Long term mortality after a single treatment course with X-rays in patients treated for ankylosing spondylitis. Br. J. Cancer, 55, 179-190.

223. Preston, D. L., Ron, E., Tokuoka, S., Funamoto, S., Nishi, N., Soda, M., Mabuchi, K. and Kodama, K. (2007) Solid cancer incidence in atomic bomb survivors: 1958-1998. Radiat. Res., 168, 1-64.

224. Egawa, H., Furukawa, K., Preston, D., et al. (2012) Radiation and smoking effects on lung cancer incidence by histological types among atomic bomb survivors. Radiat. Res., 178, 191-201.

225. Travis, L. B. (2002) Therapy-associated solid tumors. Acta Oncol., 41, 323-333.

226. Travis, L. B., Gospodarowicz, M., Curtis, R. E., et al. (2002) Lung cancer following chemotherapy and radiotherapy for Hodgkin's disease. J. Natl. Cancer Inst., 94, 182-192.

227. Travis, L. B., Curtis, R. E. and Boice, J. D. Jr. (1996) Late effects of treatment for childhood Hodgkin's disease. N. Engl. J. Med., 335, 352-353.

228. Prochazka, M., Granath, F., Ekbom, A., Shields, P. G. and Hall, P. (2002) Lung cancer risks in women with previous breast cancer. Eur. J. Cancer, $38,1520-1525$.

229. Kirova, Y. M., Gambotti, L., De Rycke, Y., Vilcoq, J. R., Asselain, B. and Fourquet, A. (2007) Risk of second malignancies after adjuvant radiotherapy for breast cancer: a large-scale, single-institution review. Int. J. Radiat. Oncol. Biol. Phys., 68, 359-363.

230. Roychoudhuri, R., Evans, H., Robinson, D. and Møller, H. (2004) Radiation-induced malignancies following radiotherapy for breast cancer. $B r$. J. Cancer, 91, 868-872.

231. Endoh, D., Suzuki, A., Kuwabara, M., Satoh, H. and Sato, F. (1987) Circadian variation in lung tumor induction with X-rays in mice. J. Radiat. Res., 28, 186-189.

232. Hashimoto, N., Endoh, D., Kuwabara, M., Satoh, H. and Sato, F. (1994) Induction of lung tumors in $\mathrm{C} 3 \mathrm{H}$ strain mice after single or fractionated irradiation with X-rays. J. Vet. Med. Sci., 56, 493-498.

233. Hashimoto, N., Endoh, D., Kuwabara, M., Satoh, H. and Sato, F. (1990) Dose and dose-splitting effects of X-rays on lung tumour induction in mice. Int. J. Radiat. Biol., 58, 351-360.

234. Focan, C. (2002) Chronobiological concepts underlying the chronotherapy of human lung cancer. Chronobiol. Int., 19, 253-273.

235. Yuhas, J. M. and Walker, A. E. (1973) Exposure-response curve for radiation-induced lung tumors in the mouse. Radiat. Res., 54, 261-273.

236. Ullrich, R. L., Jernigan, M. C. and Adams, L. M. (1979) Induction of lung tumors in RFM mice after localized exposures to X rays or neutrons. Radiat. Res., 80, 464-473.

237. Ullrich, R. L. (1983) Tumor induction in BALB/c female mice after fission neutron or gamma irradiation. Radiat. Res., 93, 506-515.

238. Ullrich, R. L., Jernigan, M. C., Satterfield, L. C. and Bowles, N. D. (1987) Radiation carcinogenesis: time-dose relationships. Radiat. Res., 111, 179-184.

239. Coggle, J. E. (1991) The role of animal models in radiation lung carcinogenesis. Radiat. Environ. Biophys., 30, 239-241.

240. Grahn, D., Lombard, L. S. and Carnes, B. A. (1992) The comparative tumorigenic effects of fission neutrons and cobalt- 60 gamma rays in the B6CF1 mouse. Radiat. Res., 129, 19-36.

241. Zhang, Y. and Woloschak, G. E. (1997) Rb and p53 gene deletions in lung adenocarcinomas from irradiated and control mice. Radiat. Res., 148, 81-89.

242. Zhang, Y. and Woloschak, G. E. (1998) Detection of codon 12 point mutations of the K-ras gene from mouse lung adenocarcinoma by 'enriched' PCR. Int. J. Radiat. Biol., 74, 43-51.

243. Tuveson, D. A. and Jacks, T. (1999) Modeling human lung cancer in mice: similarities and shortcomings. Oncogene, 18, 5318-5324.
244. Salgia, R. and Skarin, A. T. (1998) Molecular abnormalities in lung cancer. J. Clin. Oncol., 16, 1207-1217.

245. Sekido, Y., Fong, K. M. and Minna, J. D. (1998) Progress in understanding the molecular pathogenesis of human lung cancer. Biochim. Biophys. Acta, 1378, F21-F59.

246. D’Amico, D., Carbone, D., Mitsudomi, T., et al. (1992) High frequency of somatically acquired p 53 mutations in small-cell lung cancer cell lines and tumors. Oncogene, 7, 339-346.

247. Hensel, C. H., Xiang, R. H., Sakaguchi, A. Y. and Naylor, S. L. (1991) Use of the single strand conformation polymorphism technique and PCR to detect p53 gene mutations in small cell lung cancer. Oncogene, 6, 1067-1071.

248. Takahashi, T., Takahashi, T., Suzuki, H., Hida, T., Sekido, Y., Ariyoshi, Y. and Ueda, R. (1991) The p53 gene is very frequently mutated in smallcell lung cancer with a distinct nucleotide substitution pattern. Oncogene, 6, 1775-1778.

249. Sameshima, Y., Matsuno, Y., Hirohashi, S., Shimosato, Y., Mizoguchi, H., Sugimura, T., Terada, M. and Yokota, J. (1992) Alterations of the p53 gene are common and critical events for the maintenance of malignant phenotypes in small-cell lung carcinoma. Oncogene, 7, 451-457.

250. Sherr, C. J. and McCormick, F. (2002) The RB and p53 pathways in cancer. Cancer Cell, 2, 103-112.

251. Olsson, A. Y., Feber, A., Edwards, S., Te Poele, R., Giddings, I., Merson, S. and Cooper, C. S. (2007) Role of E2F3 expression in modulating cellular proliferation rate in human bladder and prostate cancer cells. Oncogene, 26, 1028-1037.

252. Vojtek, A. B. and Der, C. J. (1998) Increasing complexity of the Ras signaling pathway. J. Biol. Chem., 273, 19925-19928.

253. Califano, R., Landi, L. and Cappuzzo, F. (2012) Prognostic and predictive value of K-RAS mutations in non-small cell lung cancer. Drugs, 72, $28-36$.

254. Bongiorno, P. F., Whyte, R. I., Lesser, E. J., Moore, J. H., Orringer, M. B. and Beer, D. G. (1994) Alterations of K-ras, p53, and erbB-2/neu in human lung adenocarcinomas. J. Thorac. Cardiovasc. Surg., 107, 590-595.

255. Boice, J. D. Jr, Preston, D., Davis, F. G. and Monson, R. R. (1991) Frequent chest X-ray fluoroscopy and breast cancer incidence among tuberculosis patients in Massachusetts. Radiat. Res., 125, 214-222.

256. Land, C. E., Tokunaga, M., Koyama, K., Soda, M., Preston, D. L., Nishimori, I. and Tokuoka, S. (2003) Incidence of female breast cancer among atomic bomb survivors, Hiroshima and Nagasaki, 1950-1990. Radiat. Res., 160, 707-717.

257. Bhatia, S., Robison, L. L., Oberlin, O., Greenberg, M., Bunin, G., FossatiBellani, F. and Meadows, A. T. (1996) Breast cancer and other second neoplasms after childhood Hodgkin's disease. N. Engl. J. Med., 334, 745-751.

258. Sankila, R., Garwicz, S., Olsen, J. H., et al. (1996) Risk of subsequent malignant neoplasms among 1,641 Hodgkin's disease patients diagnosed in childhood and adolescence: a population-based cohort study in the five Nordic countries. Association of the Nordic Cancer Registries and the Nordic Society of Pediatric Hematology and Oncology. J. Clin. Oncol., 14, 1442-1446.

259. Stovall, M., Smith, S. A., Langholz, B. M., et al.; Women's Environmental, Cancer, and Radiation Epidemiology Study Collaborative Group. (2008) Dose to the contralateral breast from radiotherapy and risk of second primary breast cancer in the WECARE study. Int. J. Radiat. Oncol. Biol. Phys., 72, 1021-1030.

260. Brooks, J. D., Bernstein, L., Teraoka, S. N., et al.; WECARE Study Collaborative Group. (2012) Variation in genes related to obesity, weight, and weight change and risk of contralateral breast cancer in the WECARE Study population. Cancer Epidemiol. Biomarkers Prev., 21, 2261-2267.

261. Boice, J. D. Jr, Harvey, E. B., Blettner, M., Stovall, M. and Flannery, J. T. (1992) Cancer in the contralateral breast after radiotherapy for breast cancer. N. Engl. J. Med., 326, 781-785.

262. Thomas, D. B., Rosenblatt, K., Jimenez, L. M., et al. (1994) Ionizing radiation and breast cancer in men (United States). Cancer Causes Control, 5, 9-14. 
263. Ronckers, C. M., Erdmann, C. A. and Land, C. E. (2005) Radiation and breast cancer: a review of current evidence. Breast Cancer Res., 7, 21-32.

264. Imaoka, T., Nishimura, M., Iizuka, D., Daino, K., Takabatake, T., Okamoto, M., Kakinuma, S. and Shimada, Y. (2009) Radiation-induced mammary carcinogenesis in rodent models: what's different from chemical carcinogenesis? J. Radiat. Res., 50, 281-293.

265. Medina, D. (2000) The preneoplastic phenotype in murine mammary tumorigenesis. J. Mammary Gland Biol. Neoplasia, 5, 393-407.

266. Finerty, J. C., Binhammer, R. T., Schneider, M. and Cunningham, A. W. (1953) Neoplasms in rats exposed to single-dose total-body X radiation. J. Natl. Cancer Inst., 14, 149-157.

267. shellabarger, C. J., Cronkite, E. P., Bond, V. P. and Lippincott, S. W. (1957) The occurrence of mammary tumors in the rat after sublethal whole-body irradiation. Radiat. Res., 6, 501-512.

268. Medina, D. (2010) Of mice and women: A short history of mouse mammary cancer research with an emphasis on the paradigms inspired by the transplantation method. Cold Spring Harb. Perspect. Biol., 2, a004523.

269. Yu, Y., Okayasu, R., Weil, M. M., Silver, A., McCarthy, M., Zabriskie, R., Long, S., Cox, R. and Ullrich, R. L. (2001) Elevated breast cancer risk in irradiated $\mathrm{BALB} / \mathrm{c}$ mice associates with unique functional polymorphism of the Prkdc (DNA-dependent protein kinase catalytic subunit) gene. Cancer Res., 61, 1820-1824.

270. Moll, U., Lau, R., Sypes, M. A., Gupta, M. M. and Anderson, C. W. (1999) DNA-PK, the DNA-activated protein kinase, is differentially expressed in normal and malignant human tissues. Oncogene, 18, 31143126.

271. Ethier, S. P. and Ullrich, R. L. (1984) Factors influencing expression of mammary ductal dysplasia in cell dissociation-derived murine mammary outgrowths. Cancer Res., 44, 4523-4527.

272. Ullrich, R. L. and Preston, R. J. (1991) Radiation induced mammary cancer. J. Radiat. Res., 32, 104-109.

273. Deome, K. B., Faulkin, L. J. Jr, Bern, H. A. and Blair, P. B. (1959) Development of mammary tumors from hyperplastic alveolar nodules transplanted into gland-free mammary fat pads of female $\mathrm{C} 3 \mathrm{H}$ mice. Cancer Res., 19, 515-520.

274. Deome, K. B., Miyamoto, M. J., Osborn, R. C., Guzman, R. C. and Lum, K. (1978) Detection of inapparent nodule-transformed cells in the mammary gland tissues of virgin female $\mathrm{BALB} / \mathrm{cfC} 3 \mathrm{H}$ mice. Cancer Res., 38, 2103-2111.

275. Ethier, S. P. and Ullrich, R. L. (1982) Detection of ductal dysplasia in mammary outgrowths derived from carcinogen-treated virgin female BALB/c mice. Cancer Res., 42, 1753-1760.

276. Ethier, S. P., Adams, L. M. and Ullrich, R. L. (1984) Morphological and histological characteristics of mammary dysplasias occurring in cell dissociation-derived murine mammary outgrowths. Cancer Res., 44, 4517-4522.

277. Barcellos-Hoff, M. H. (1993) Radiation-induced transforming growth factor beta and subsequent extracellular matrix reorganization in murine mammary gland. Cancer Res., 53, 3880-3886.

278. Barcellos-Hoff, M. H. (1998) The potential influence of radiationinduced microenvironments in neoplastic progression. J. Mamm. Gland Biol. Neoplasia, 3, 165-175.

279. Barcellos-Hoff, M.H. (2005) How tissues respond to damage at the cellular level: orchestration by transforming growth factor-\{beta\} (TGF\{beta\}). BJR Suppl/BIR, 27, 123-127.
280. Barcellos-Hoff, M. H. (2005) Integrative radiation carcinogenesis: interactions between cell and tissue responses to DNA damage. Semin. Cancer Biol., 15, 138-148.

281. Ethier, S. P. and Ullrich, R. L. (1982) Induction of mammary tumors in virgin female BALB/c mice by single low doses of 7,12-dimethylbenz[a] anthracene. J. Natl. Cancer Inst., 69, 1199-1203.

282. Ullrich, R. L., Bowles, N. D., Satterfield, L. C. and Davis, C. M. (1996) Strain-dependent susceptibility to radiation-induced mammary cancer is a result of differences in epithelial cell sensitivity to transformation. Radiat. Res., 146, 353-355.

283. Danielson, M. (1984) Hemodynamic effects of diuretic therapy in hypertension. Acta Pharmacol. Toxicol. (Copenh)., 54, 33-36.

284. Nguyen, D. H., Oketch-Rabah, H. A., Illa-Bochaca, I., et al. (2011) Radiation acts on the microenvironment to affect breast carcinogenesis by distinct mechanisms that decrease cancer latency and affect tumor type. Cancer Cell, 19, 640-651.

285. Barcellos-Hoff, M. H. and Brooks, A. L. (2001) Extracellular signaling through the microenvironment: a hypothesis relating carcinogenesis, bystander effects, and genomic instability. Radiat. Res., 156, 618-627.

286. Barcellos-Hoff, M. H., Park, C. and Wright, E. G. (2005) Radiation and the microenvironment - tumorigenesis and therapy. Nat. Rev. Cancer, 5, 867-875.

287. Barcellos-Hoff, M. H. and Medina, D. (2005) New highlights on stromaepithelial interactions in breast cancer. Breast Cancer Res., 7, 33-36.

288. Alberts, B. (2008) Molecular Biology of the Cell, $5^{\text {th }}$ edn. Garland Science, New York.

289. Andarawewa, K. L., Paupert, J., Pal, A. and Barcellos-Hoff, M. H. (2007) New rationales for using TGFbeta inhibitors in radiotherapy. Int. J. Radiat. Biol., 83, 803-811.

290. Andarawewa, K. L., Erickson, A. C., Chou, W. S., Costes, S. V., Gascard, P., Mott, J. D., Bissell, M. J. and Barcellos-Hoff, M. H. (2007) Ionizing radiation predisposes nonmalignant human mammary epithelial cells to undergo transforming growth factor beta induced epithelial to mesenchymal transition. Cancer Res., 67, 8662-8670.

291. Castiglioni, F., Terenziani, M., Carcangiu, M. L., et al. (2007) Radiation effects on development of HER2-positive breast carcinomas. Clin. Cancer Res., 13, 46-51.

292. Arima, Y., Hayashi, H., Sasaki, M., et al. (2012) Induction of ZEB proteins by inactivation of RB protein is key determinant of mesenchymal phenotype of breast cancer. J. Biol. Chem., 287, 7896-7906.

293. Robbins, M. E. and Zhao, W. (2004) Chronic oxidative stress and radiation-induced late normal tissue injury: a review. Int. J. Radiat. Biol., 80, 251-259.

294. Kuefner, M. A., Brand, M., Ehrlich, J., Braga, L., Uder, M. and Semelka, R. C. (2012) Effect of antioxidants on X-ray-induced $\gamma$-H2AX foci in human blood lymphocytes: preliminary observations. Radiology, 264, 59-67.

295. Margulies, B. S., Damron, T. A. and Allen, M. J. (2008) The differential effects of the radioprotectant drugs amifostine and sodium selenite treatment in combination with radiation therapy on constituent bone cells, Ewing's sarcoma of bone tumor cells, and rhabdomyosarcoma tumor cells in vitro. J. Orthop. Res., 26, 1512-1519.

296. Sieber, F., Muir, S. A., Cohen, E. P., North, P. E., Fish, B. L., Irving, A. A., Mäder, M. and Moulder, J. E. (2009) High-dose selenium for the mitigation of radiation injury: a pilot study in a rat model. Radiat. Res., 171, $368-373$. 